\title{
Relative paleointensity (RPI) in the latest Pleistocene (10-45 ka) and implications for deglacial atmospheric radiocarbon
}

\author{
Channell J. E. T. ${ }^{1,}{ }^{\star}$, Hodell D. A. ${ }^{2}$, Crowhurst S. J. ${ }^{2}$, Skinner L. C. ${ }^{2}$, Muscheler R. ${ }^{3}$
}

1 Univ Florida, Dept Geol Sci, 241 Williamson Hall,POB 112120, Gainesville, FL 32611 USA.

2 Univ Cambridge, Dept Earth Sci, Godwin Lab Palaeoclimate Res, Downing St, Cambridge CB2 3EQ, England.

${ }^{3}$ Lund Univ, Quaternary Sci, Dept Geol, Solvegatan 12, SE-22362 Lund, Sweden.

*Corresponding author : J. E. T. Channel, email address : jetc@ufl.edu

\begin{abstract}
:
We report magnetic properties and relative paleointensity (RPI) proxies from a suite of 10 conventional piston cores and Kasten cores from the SW Iberian Margin collected during cruise JC089 of the RSS James Cook in August 2013. Mean sedimentation rates are in the 10-20 cm/kyr range. Age models were acquired by correlation of $\mathrm{Ca} / \mathrm{Ti}$ and $\mathrm{Zr} / \mathrm{Sr} \mathrm{XRF}$ core-scanning data to $\mathrm{L}^{*}$ reflectance from the Cariaco Basin that is, in turn, tied to the Greenland ice-core chronology. The natural remanent magnetization (NRM) is represented by a single magnetization component carried by a low-coercivity mineral (magnetite), although reflectance and bulk magnetic properties indicate the presence of a high-coercivity (hematitic) magnetic phase, possibly from eolian dust. The presence of fine-grained hematite means that the sediments are not ideal for RPI studies, however the detrital hematite does not appear to contribute to the NRM or anhysteretic remanent magnetization (ARM). In order to test the usefulness of the RPI data, we construct a stack of 12 RPI records from the SW Iberian Margin for the 0-45 ka interval and compare it with a stack of 12 globally distributed marine and lake records, chosen on the basis of mean sedimentation rates $(>15 \mathrm{~cm} / \mathrm{kyr}$ ) and superior age models. The two stacks are similar, but different from published RPI stacks, particularly for the 10-30 ka interval, and imply a virtual axial dipole moment (VADM) high at $\sim 15-18 \mathrm{ka}$ followed by a drop in field strength from $\sim 15$ to $13 \mathrm{ka}$. A revised VADM estimate calculated from Greenland 10Be ice-core flux using a contemporary age model is remarkably consistent with the new overall RPI stack, based on Iberian Margin and global RPI records. The elevated atmospheric $14 \mathrm{C}$ levels of the last ice age cannot, however, be fully explained by this RPI stack although relative changes such as the long-term drop in atmospheric $14 \mathrm{C}$ from 30 to $15 \mathrm{ka}$ are reproduced, supporting the hypothesis of a combined influence of production rate and ocean ventilation on $14 \mathrm{C}$ during the last ice age.
\end{abstract}




\section{Highlights}

- Revised view of relative paleointensity for the latest Quaternary $(0-45 \mathrm{ka})$. S Stack of SW Iberian and global relative paleointensity records for $0-45 \mathrm{ka}$. RPI stack consistent with recalculated ${ }^{10} \mathrm{Be}$-based estimate of field intensity. Implications for the carbon cycle, ocean ventilation, and the "mystery interval".

Keywords : Relative geomagnetic paleointensity, Latest Quaternary, SW Iberian margin, Carbon cycle, Ice-core Be-10, "Mystery interval", Atmospheric radiocarbon 
46 Consistent correlation of sedimentary relative paleointensity (RPI) proxies to

47 oxygen isotope data over the last 1-2 Myrs (e.g., Channell et al., 2009; Xuan et al., 2016)

48 has shown that RPI proxies in sediments can reflect the Earth's axial dipole (AD) field

49 and therefore provide a signal suitable for global stratigraphic correlation. This

50 conclusion is supported by the consistent picture of dipole field strength from RPI and

51 from sedimentary ${ }^{10} \mathrm{Be} /{ }^{9} \mathrm{Be}$ ratios back to $850 \mathrm{ka}$ (e.g., Simon et al., 2016). Because the

52 strength of the AD field is an important control on atmospheric cosmogenic isotope

53 production, RPI records have implications for the calibration of radiocarbon dates and for

54 the carbon cycle including the apparent drop in atmospheric $\Delta^{14} \mathrm{C}$ in the "mystery

55 interval” at 17.5-14.5 kyr (Broecker and Barker, 2007).

56 The Holocene (0-11.5 ka) record of paleointensity has been modeled from

57 archeomagnetic and lava-flow data (Korte et al., 2009, 2011; Pavon-Carrasco et al.,

58 2014) indicating a pattern of AD field intensity changes characterized by a broad high in

59 intensity at $\sim 1-3 \mathrm{ka}$, preceded by a broad low in the 5-7 ka interval (Fig. 1b). Beyond the

60 range of archeomagnetic data, latest Pleistocene (11.5-45 ka) sedimentary RPI data have

61 been compiled into regional and global stacks (Laj et al., 2000, 2004; Stoner et al., 2002;

62 Valet et al., 2005; Channell et al., 2009; Ziegler et al., 2011), but with little agreement 
63 between stacks, or individual records, for the 10-30 ka interval (Fig. 1a). The poor 64 consistency of sedimentary RPI data since the time of the Mono Lake ( $\sim 34 \mathrm{ka})$ and 65 Laschamp ( $\sim 1 \mathrm{ka}$ ) excursions (Fig. 1a) is attributed to drilling disturbance in the 66 uppermost few meters of recovered sediment sequences.

67 Absolute paleointensity data from volcanics have not contributed significantly to

68 the paleointensity time-series for the 10-30 ka interval for several reasons: lava sequences

69 are plagued by unknown time-gaps between flows, ${ }^{40} \mathrm{Ar} /{ }^{39} \mathrm{Ar}$ dating has poor precision

70 for young ( $<40 \mathrm{ka}$ ) ages, scarcity of robust radiocarbon age control, and scatter in

71 absolute paleointensity determinations when plotted versus age particularly for the 10-30

72 ka interval (e.g., Teanby et al., 2002; Pressling et al., 2006; Genevey et al., 2008; Laj et 73 al., 2014).

74 Using models of cosmogenic nuclide production (Masarik and Beer, 1999),

75 Muscheler et al. (2005) calculated the virtual axial dipole moment (VADM)

76 corresponding to the flux of cosmogenic isotopes in ice cores for ${ }^{36} \mathrm{Cl}$ (Baumgartner et

77 al., 1998; Wagner et al., 2000) and ${ }^{10}$ Be (Yiou et al., 1997; Finkel and Nishiizumi, 1997).

78 Estimates of atmospheric ${ }^{14} \mathrm{C}$ activity have been derived from independent age control on

79 radiocarbon ages from stalagmites (Beck et al., 2001; Wang et al., 2001; Southon et al.,

80 2011), corals (Fairbanks et al., 2005), lake varves (Bronk Ramsey et al., 2012) and from

81 the correlation of marine sediment cores to Greenland ice (Hughen et al., 2004; Peterson

82 et al., 2000; Bard et al., 2004). VADM estimates derived from atmospheric ${ }^{14} \mathrm{C}$

83 (Muscheler et al., 2005) are not consistent with estimates from ${ }^{36} \mathrm{Cl}$ and ${ }^{10} \mathrm{Be}$ from

84 Greenland ice, particularly for 10-30 ka (Fig. 1b). Discrepancies may be due to differing

85 transport pathways for ${ }^{36} \mathrm{Cl}$ and ${ }^{10} \mathrm{Be}$ from the atmosphere to ice, diffusion of ${ }^{36} \mathrm{Cl}$ in firn

86 (not likely in Greenland), and changes in the carbon cycle, particularly changes in ocean

87 ventilation (e.g. Skinner and Shackleton, 2004; Muscheler et al., 2004; Robinson et al.,

88 2005; Skinner et al., 2010; Chen et al., 2015). Furthermore, revisions in ice-core

89 timescales directly impact the radionuclide flux calculation. For the last glacial maximum

90 (LGM) interval, the latest Greenland ice core timescale (Svensson et al., 2008) results in

91 adjustments to the ${ }^{10} \mathrm{Be}$-based VADM estimates of Muscheler et al. (2005).

92 Magnetic concentration parameters in sediments, such as susceptibility or

93 anhysteretic remanent magnetization (ARM) intensity, are less affected by subtle drilling 
94 disturbance than natural remanent magnetization (NRM) intensities. Sedimentary NRM

95 intensities depend on magnetic grain alignment, and are an essential entity in RPI

96 proxies. Published RPI stacks (Fig. 1a) rely largely on cores collected from the Marion

97 Dufresne (MD) using the Calypso corer, and cores collected using the Advanced Piston

98 Corer (APC) of the Ocean Drilling Program and Integrated Ocean Drilling Program

99 (ODP/IODP). The stretching (oversampling) of the upper part of sediment cores collected

100 by the Calypso corer has been well documented (Skinner and McCave, 2003; Széréméta

101 et al., 2004). Deformation of the upper part of APC cores is less well documented

102 although familiar to shipboard scientists who regularly observe poorly consolidated or

103 "soupy" conditions in the topmost few meters of recovered sediment. Drilling disturbance

104 of APC cores down-section has been associated with shearing of the sediment as the APC

105 core-barrel rips through the sediment and physically deflects the ancient magnetization

106 particularly at core edges (Acton et al., 2002). This secondary magnetization component

107 tends to have a coercivity spectrum that overlaps with the ancient (primary)

108 magnetization, being largely produced by magnetic grain deflection, and therefore the

109 primary magnetization is often not recoverable through laboratory demagnetization

110 (Acton et al., 2002).

111 The influence of drilling disturbance can be mitigated to some extent by choosing

112 sites with elevated mean sedimentation rates, so that the uppermost few meters of the

113 sediment sequence have a more restricted (younger) age range, and by choice of coring

114 and sampling methods. With these factors in mind, we investigated the RPI record for the

115 latest Quaternary (0-45 ka) from a suite of short (NIOZ-type) piston cores and Kasten

116 cores (Zangger and McCave, 1990) collected from the SW Iberian Margin during cruise

117 JC089 of the RSS James Cook in August 2013 (Hodell et al., 2014). The coring methods

118 used during JC089 are not immune to drilling disturbance; however, traditional piston

119 cores and especially square barrel Kasten cores are expected to be less susceptible to

120 drilling disturbance than Calypso or APC cores (Skinner and McCave, 2003). The JC089

121 sites are located on a spur on the continental slope of the Iberian Margin (Promonotorio

122 dos Principes de Avis) that is elevated above the abyssal plain and the influence of

123 turbidites (Fig. 2). Uppermost Quaternary sediments comprise greenish-gray hemipelagic

124 nannofossil mud and clays with mean sedimentation rates in the $10-20 \mathrm{~cm} / \mathrm{kyr}$ range 
125 (Table 1). Our discussion includes JC089 cores collected from water depths $>2500 \mathrm{~m}$

126 (Table 1); cores collected at shallower water depth during the same cruise display more

127 significant heterogeneity in both lithology and magnetic properties.

128 The site locations are in the vicinity of Core MD95-2042 (Fig. 2) made famous by

129 Shackleton et al. $(2000,2004)$ due to their observation that planktic and benthic $\delta^{18} \mathrm{O}$

130 records mimic Greenland and Antarctic ice-core air-temperature records, respectively. As

131 a result, sediment cores from this part of the Iberian Margin have potential for precise age

132 control over the last glacial cycle through correlation to ice-core chronologies. One of the

133 sites discussed here (Station 6, Table 1) is at the same location as Core MD01-2444 (Fig.

134 2), and is close to (1.8 $\mathrm{km}$ from) IODP Site U1385. At MD01-2444 and Site U1385,

135 precise age models have been constructed by correlation of oxygen isotope and X-ray

136 fluorescence (XRF) core-scanning data to Core MD99-2334K and ice-core chronologies

137 (Skinner et al., 2003; Skinner and Shackleton, 2004; Hodell et al., 2013, 2015; Freeman

138 et al., 2016). The SW Iberian Margin has distinct chronological advantages relative to

139 most marine sites where traditional oxygen isotope stratigraphy usually has limited

140 resolution, even at glacial terminations, resulting in poor stratigraphic control within the

141 last glacial cycle. Core MD95-2042 was one of several cores used to build the Portuguese

142 Margin RPI stack (Thouveny et al., 2004) that was accompanied by sedimentary ${ }^{10} \mathrm{Be} /{ }^{9} \mathrm{Be}$

143 data (Carcaillet et al., 2004; Ménabréaz et al., 2011). Although magnetite dominates the

144 magnetic properties of Cores MD95-2042 and MD01-2444, the suitability of these

145 sediments for RPI studies is compromised by the presence of a high-coercivity magnetic

146 phase (Moreno et al., 2002), believed to be hematite sourced from eolian dust, or possibly

147 from riverine input (Channell et al., 2013; Hodell et al., 2013).

149 2. XRF methods and age control

150 The JC089 cores were scanned at the University of Cambridge using an Avaatech

151 XRF core scanner ( $3^{\text {rd }}$ generation) to obtain semi-quantitative elemental data. The surface

152 of the cores was scraped clean then covered with $4 \mu \mathrm{m}$ thick SPEXCertiPrep Ultralene

153 foil to avoid contamination and to prevent the cores drying out and cracking. Each

154 section was measured at three different voltages and currents: $10 \mathrm{kV}$ and $750 \mathrm{~mA}, 30 \mathrm{kV}$

155 and $500 \mathrm{~mA}$, and at $50 \mathrm{kV}$ and $1000 \mathrm{~mA}$. The entire length of each core was analyzed at 
156 5-mm resolution with an irradiated surface length and width of $5 \mathrm{~mm}$ (downcore) and 12

$157 \mathrm{~mm}$ (cross core). The count time was $60 \mathrm{~s}$ for each measurement. Element intensities

158 were obtained by post-processing of the XRF spectra using the Canberra WinAxil

159 software with standard software settings and spectrum-fit models.

160 Sediments deposited on the SW Iberian Margin were particularly responsive to

161 Quaternary climate on both millennial and orbital timescales, being optimally positioned

162 to respond to fluctuations in sea-surface and bottom-water temperatures (Shackleton et

163 al., 2000, 2004; Skinner et al., 2003, 2007; Hodell et al., 2013, 2015). Variations in

164 carbonate concentrations in sediments from this region have been associated with

165 changes in terrigenous supply (Thomson et al., 1999, 2000), although surface-water

166 productivity and sea-surface temperatures affect carbonate content on millennial

167 timescales (Hodell et al., 2013). For Core MD01-2444, same location as JC089-06 (Fig.

168 2), the $\mathrm{Ca}$ /Ti ratio from XRF core-scanning provides a reliable proxy for wt $\% \mathrm{CaCO}_{3}$,

169 and largely reflects the mixing ratio of biogenic $(\mathrm{Ca})$ and detrital (Ti) components

170 (Hodell et al., 2013). The Ca/Ti ratio at MD01-2444 mimics planktic $\delta^{18} \mathrm{O}$ and can be

171 correlated to the Greenland ice-core $\delta^{18} \mathrm{O}$ record for the last glacial cycle (Hodell et al., 172 2013).

173 For this study, age models for JC089 cores were constructed by correlating $\mathrm{Ca} / \mathrm{Ti}$

174 and $\mathrm{Zr} / \mathrm{Sr}$ signals to the $\mathrm{L}^{*}$ reflectance record from Cariaco Basin (Deplazes et al., 2013).

175 The Cariaco age model is a hybrid of layer counting, radiocarbon, and correlation of the

$176 \mathrm{~L}^{*}$ record to the ice core $\delta^{18} \mathrm{O}$ record of NGRIP using the GICC05 age scale for 0-60 ka

177 (see supplement of Deplazes et al., 2013). Peaks in Ca/Ti mark interstadials whereas

$178 \mathrm{Zr} / \mathrm{Sr}$ values are generally higher during stadials, particularly Heinrich stadials (Fig. 3;

179 Figs. S1-S4). We used the Cariaco Basin record as the intermediary to Greenland because

180 Heinrich stadials are well expressed in the Cariaco color record, whereas they are muted

181 in the Greenland ice core $\delta^{18} \mathrm{O}$ and dust record. There are only very minor differences

182 between our age models constructed via Cariaco and those of Freeman et al. (2016) in

183 which the same JC089 cores were correlated directly to Greenland (Figs. S5 and S6).

184 Precise age control from correlation to ice-core chronologies is a result of

185 heterogeneity in geochemistry and lithology as a result of the high fidelity response of

186 these sediments to climatic change. The heterogeneity that facilitates the age control is, 
187 on the other hand, not advantageous for relative paleointensity determinations that rely on 188 uniformity in magnetic properties.

3. Magnetic measurements and methods

Magnetic measurements using a $2 \mathrm{G}$ Enterprises pass-through cryogenic magnetometer (Weeks et al., 1993) were made on u-channel samples $\left(2 \times 2 \times 150 \mathrm{~cm}^{3}\right)$

193 collected from the split face of piston cores and the scraped side of Kasten cores.

194 Cleaning/scraping of the surfaces prior to $\mathrm{u}$-channel sampling is particularly critical for

195 Kasten cores because of the likelihood of coring disturbance close to core-walls and

196 hence close to the u-channel sample. NRM was measured prior to alternating field (AF)

197 demagnetization and after demagnetization at peak fields of 10-30 mT in 5mT steps, 30-

$19860 \mathrm{mT}$ in $2.5 \mathrm{mT}$ steps and 60-70 $\mathrm{mT}$ in $5 \mathrm{mT}$ steps, and $80 \mathrm{mT}$. All magnetometer

199 measurements were carried out at $1-\mathrm{cm}$ spacing, with a $10-\mathrm{cm}$ leader and trailer at the

200 ends of the u-channel sample. NRM component magnetizations were determined in a 201 uniform 20-80 mT demagnetization range, and maximum angular deviation (MAD)

202 values were determined using the standard method (Kirschvink, 1980) and the software 203 of Xuan and Channell (2009). Volume magnetic susceptibility was then measured at 1204 cm spacing using a susceptibility track designed for u-channel samples (Thomas et al., 205 2003). ARM was then imposed along the long-axis of $u$-channel samples using a $50 \mu \mathrm{T}$ 206 DC field and a $100 \mathrm{mT}$ alternating field. The ARM was then AF demagnetized at peak 207 fields of 10-60 mT in $5 \mathrm{mT}$ steps, and 60-80 $\mathrm{mT}$ in $10 \mathrm{mT}$ steps. ARM was then 208 incrementally imposed along the axis of each u-channel sample using a uniform $(50 \mu \mathrm{T})$ 209 DC field and stepwise increasing alternating fields, using the same AF increments as for 210 ARM demagnetization. Next, an isothermal remanent magnetization (IRM) was imposed 211 along the axis of each $\mathrm{u}$-channel using a DC field of $300 \mathrm{mT}$, and the $\mathrm{IRM}_{0.3 \mathrm{~T}}$ was then 212 demagnetized at the same peak field used for ARM demagnetization. Finally, an IRM $_{1 T}$ 213 was imposed using a DC field of $1 \mathrm{~T}$, and again demagnetized using the same alternating 214 fields used for ARM and $\mathrm{IRM}_{0.3 \mathrm{~T}}$.

215 Relative paleointensity (RPI) proxies in sediments are determined by

216 normalization of NRM intensity by the intensity of a laboratory-induced magnetization

217 designed to activate the same magnetic grains that contribute to the NRM (Levi and 
218 Banerjee, 1976; Tauxe, 1993). The most commonly used normalizers are ARM and IRM.

219 The NRM and the normalizer should be carried by magnetite in a restricted grain size and 220 concentration range (see Tauxe, 1993). Here we acquire potential paleointensity proxies

221 for the 20-60 mT demagnetization/acquisition interval using four slopes: NRM

222 demagnetization versus ARM demagnetization, NRM demagnetization versus ARM

223 acquisition, NRM demagnetization versus IRM $_{0.3 T}$ demagnetization, and NRM

224 demagnetization versus $\mathrm{IRM}_{1 \mathrm{~T}}$ demagnetization. The software of Xuan and Channell

225 (2009) allows linear correlation coefficients (r) to be determined for slopes determined at 226 each 1-cm spaced measurement position.

227 A Princeton Measurements Corp. vibrating sample magnetometer (VSM) was

228 used to determine hysteresis ratios and first order reversal curves (FORCs) on sediment

229 samples encased in \#4 gel-caps. No FORCs are reproduced in this paper as the FORC

230 results and conclusions are very similar to those for Core MD01-2444 (Channell et al., 231 2013).

232

233 4. Magnetic properties

234 NRM has low coercivity in Core MD01-2444 (Channell et al., 2013) and at 235 neighboring sites including MD95-2042 (Thouveny et al., 2004). The magnetic properties 236 of Core MD01-2444 are dominated by biogenic and detrital magnetite with a greater 237 proportion of biogenic magnetite in interglacial stages (Channell et al., 2013). Fine238 grained hematite in Core MD01-2444 is indicated by S-ratios and a* (570-560 nm) 239 reflectance data, and it was associated with eolian Saharan dust due to precessional power

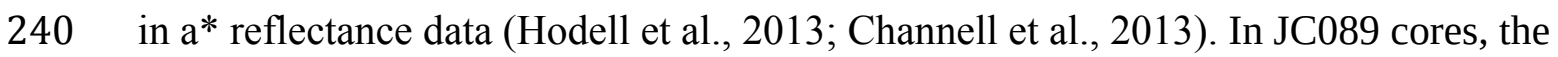
241 NRM component directions have low coercivity, are associated with low $\left(<5^{\circ}\right)$ MAD 242 values, and inclinations are consistent with site latitude although with shallower 243 inclinations at depth (Fig. 4) possibly associated with sediment compaction. The 244 characteristic (primary) NRM magnetization components are not obviously correlated 245 amongst the cores, and the Laschamp or Mono Lake magnetic excursions are not 246 observed in any of the JC089 cores, or in Core MD01-2444, although the Laschamp 247 excursion is apparently represented by divergent declinations for several adjacent $\mathrm{u}-$ 248 channel measurement positions in Core MD95-2042 (Thouveny et al., 2004). Recordings 
249 of directional aberrations associated with Laschamp and Mono Lake excursions are rare

250 in sediments with similar $(\sim 15 \mathrm{~cm} / \mathrm{kyr})$ sedimentation rates, presumably due to filtering

251 of the directional signal by non-instantaneous remanence-acquisition, the stochastic

252 nature of sediment accumulation on short timescales, and the centennial-scale duration of

253 these two directional excursions (see Laj and Channell, 2015).

254 Orthogonal projections of u-channel AF demagnetization data of JC089 Kasten

255 cores (Fig. 5a) are displayed at sediment depths of $100 \mathrm{~cm}, 200 \mathrm{~cm}, 250 \mathrm{~cm}$, and 350

$256 \mathrm{~cm}$ (300 cm corresponds to a section break). For one core $(06-5 \mathrm{~K})$, the projection at 330

$257 \mathrm{~cm}$ is shown because the core does not reach $350 \mathrm{~cm}$ (Table 1). A single NRM

258 magnetization component appears to be present throughout the suite of cores, and the

259 maximum peak field (80 mT) implies low coercivity NRM carrier(s). Orthogonal

260 projections from samples at these depths in JC089 piston cores are shown in Figure S7.

261 Volume susceptibility shows subdued variability other than during HS4 (Fig. 6d)

262 Variations in the magnetite grain-size parameter $\kappa_{\mathrm{arm}} / \kappa$ indicate coarser magnetite during

263 Heinrich stadials (HS), a progressive fining of grain size at Termination I, and fine

264 magnetite grain sizes in the early Holocene (Fig. 6c). The change in $\kappa_{\mathrm{ARM}} / \kappa$ at

265 Termination I is controlled by an increase, by a factor of $\sim 2$, of ARM intensity as the

266 concentration of fine-grained biogenic magnetite increases relative to coarser detrital

267 magnetite in the Holocene. The plot of $\kappa_{\text {arm }}$ versus susceptibility ( $\left.\kappa\right)$ indicates fine

268 magnetite grain sizes apart from during HS4 (Fig. 6a), and the range of magnetite grain

269 sizes is consistent with estimates from the hysteresis (Day et al., 1977) plot (Fig. 6b). Our

270 interpretation of the magnetic properties of JC089 cores is consistent with the

271 interpretations from Core MD01-2444 where magnetic properties are controlled by

272 variations in the proportion of biogenic and detrital magnetite (Channell et al., 2013) with

273 interglacial stages, including the Holocene, characterized by enhanced concentration of

274 biogenic magnetite, whereas Heinrich stadials have enhanced detrital input associated

275 with sea level low-stands. High susceptibility and coarse magnetite grain size during HS4

276 (Fig. 6) are consistent with the presence of ice-rafted debris (IRD). Heinrich stadials tend

277 to be associated with lower values of $\kappa_{\mathrm{arm}} / \kappa$ (coarser magnetite grain size), higher

278 susceptibility and higher S-ratios, but only HS4 has the prominent susceptibility signal

279 denoting IRD (Fig. 6). 

mineral was detected by Moreno et al. (2002) and Channell et al. (2013), respectively, and attributed to eolian dust (Hodell et al., 2013). In Core MD01-2444, isothermal remanent magnetization acquired in magnetizing fields of $300 \mathrm{mT}\left(\mathrm{IRM}_{0.3 \mathrm{~T}}\right)$ and $1 \mathrm{~T}$ $\left(\mathrm{IRM}_{1 \mathrm{~T}}\right)$ yield S-ratios (determined as $\mathrm{IRM}_{0.3 \mathrm{~T}} / \mathrm{IRM}_{1 \mathrm{~T}}$ after demagnetization of both IRMs at peak fields of $30 \mathrm{mT}$ ) with values in the 0.8-0.95 range with lower values (high coercivities) associated with glacial and stadial climatic episodes (see Fig. 5 in Channell et al., 2013). For JC089 cores, the values of $\mathrm{IRM}_{0.3 \mathrm{~T}}$ and $\mathrm{IRM}_{1 \mathrm{~T}}$ yield $\mathrm{S}$-ratios in a similar (0.8-0.95) range although values are variable from core to core (Fig. 6e). Using two of the sediment depths $(100 \mathrm{~cm}$ and $200 \mathrm{~cm})$ used for orthogonal projections of NRM (Fig. 5a), normalized intensities ( $\mathrm{Jr} / \mathrm{Jo})$ of NRM indicate higher coercivity in the 20-80 $\mathrm{mT}$ peak field demagnetization range than for ARM (Fig. 5b). Both IRM $\mathrm{I}_{0.3 \mathrm{~T}}$ and $\mathrm{IRM}_{1 \mathrm{~T}}$

292 have higher coercivity in the 60-80 $\mathrm{mT}$ range than NRM and ARM (Fig. 5b). The 293 progressive bifurcation with increasing peak fields for IRM $\mathrm{I}_{0.3 \mathrm{~T}}$ and $\mathrm{IRM}_{1 \mathrm{~T}}$ denotes the 294 high-coercivity signal of the hematitic dust that is apparently less important in NRM and 295 ARM (Fig. 5b).

5. Relative paleointensity (RPI) proxies

RPI proxies in these sediments are complicated by the presence of biogenic magnetite (see Roberts et al., 2012), and by the presence of detrital hematite, as RPI proxies traditionally require magnetite to be the sole remanence carrier with uniformity in magnetite grain size and concentration (Tauxe, 1993). On the other hand, the hematite in Core MD01-2444 is from eolian dust, or possibly from riverine input, and therefore detrital (Hodell et al., 2013), and therefore may not contribute to the NRM due to the low intrinsic magnetization (alignment efficiency) of hematite. The possibility of acquiring useful RPI proxies depends on the extent to which the detrital hematite contributes to the NRM and to the normalizers used to acquire the RPI proxies.

Core MD01-2444 and Cores 06-4K and 06-5K were collected at the same location

308 (Fig. 2), and yet the MD01-2444 apparent sedimentation rates are about twice those at 309 06-4K and 06-5K (Fig. 7), presumably because of relative stretching of the MD core. The two Kasten cores (06-4K and 06-5K) have similar but not identical sedimentation rates 
311 with differences attributable to differential compaction (Figs. S5 and S6). Clearly, cores

312 collected at nominally the same location are not identical, and depend on the coring

313 method, and perhaps on the precise location of core penetration. RPI proxies from the

314 three cores differ, particularly in the 12-15 ka interval (Fig. 7). The $\mathrm{Ca} / \mathrm{Ti}$ and $\mathrm{Zr} / \mathrm{Sr}$ ratios

315 for 06-4K (Fig. 3; Figs. S2 and S4) imply a hiatus that apparently removed part or all of

316 the Younger Dryas, which appears to be recorded in 06-5K (Fig. 3). Note that all four

317 RPI proxies (NRM/ARM, NRM/ARMAQ, NRM/IRM ${ }_{0.3 \mathrm{~T}}, \mathrm{NRM} / \mathrm{IRM}_{1 \mathrm{~T}}$ ) are similar in

318 the glacial interval, but differ in the Holocene, although correlation coefficients (r)

319 associated with all slopes are close to unity, implying well-defined slopes (Fig. 7). A

320 similar difference in the four RPI proxies was observed in the Holocene at MD01-2444

321 and was attributed to under-normalization by IRM due to high concentration of ultra-fine

322 biogenic magnetite (Channell et al., 2013). A fine-grained high-coercivity hematitic

323 phase would be expected to affect the four proxies differently, and the general similarity

324 of the RPI proxies implies that the hematite does not contribute significantly to NRM

325 intensity or to the normalizers used to generate the RPI proxies.

326 For other JC089 cores (Table 1), linear sedimentation rates are not identical for

327 Kasten and piston cores from the same location, attributable to differential coring

328 disturbance, with the piston cores having generally higher linear sedimentation rates (Fig.

329 8; Figs. S5 and S6). The four RPI proxies (NRM/ARM, NRM/ARMAQ, NRM/IRM ${ }_{0.3 T}$,

$330 \mathrm{NRM} / \mathrm{IRM}_{1 \mathrm{~T}}$ ) are generally similar although again there is the tendency, as in Cores 06-

$3314 \mathrm{~K}$ and 06-5K (Fig. 7), for under-normalization by IRM in the Holocene where the

332 concentration of ultra-fine biogenic magnetite is greater (Fig. 8). The linear correlation

333 coefficients ( $\mathrm{r}$ ) are generally $>0.98$, indicating that the slopes (RPI proxies) are well

334 defined. Note that all RPI proxies (slopes) were determined for the 20-60 mT

335 demagnetization/acquisition range in an effort to exclude the enhanced influence of

336 hematite at peak fields $>60 \mathrm{mT}$ (Fig. 5b).

337

338 6. Relative paleointensity (RPI) stacks

339 In order to test the fidelity of the RPI proxies, we constructed a RPI stack for the

340 SW Iberian Margin for the 0-45 ka interval for comparison with other records. The

341 Iberian Margin Stack (Fig. 9a) includes the ten JC089 cores (Table 1, Fig. 9b), the RPI 
342 record from Core MD01-2444 (Table 2, Channell et al., 2013) and the Portuguese Margin

343 Stack (Table 2, Thouveny et al., 2004). All records are on their individual age models,

344 with no age adjustments or record matching. The JC089 and MD01-2444 RPI proxies

345 that are incorporated in the stack are the slopes of NRM/ARM. Each record was

346 interpolated to a uniform 0.5-kyr sampling spacing, and set to a common mean and

347 common standard deviation. The stack is the mean at each 0.5-kyr data step, giving equal

348 weight to each of 12 records (Fig. 9a).

349 The choice of records for inclusion in the stack from outside the Iberian Margin

350 for 0-45 ka (Table 2) was based on mean sedimentation rate ( $>15 \mathrm{~cm} / \mathrm{kyr}$ ) and deemed

351 adequacy of age models. The vast majority of marine cores do not have adequate

352 sedimentation rates, nor do they have age control in the last glacial other than

353 identification from $\delta^{18} \mathrm{O}$ of the last glacial termination. The twelve records that are

354 included in the stack from outside the Iberian Margin (Fig. 9c) are listed in Table 2. Each

355 record was placed on its published age model, was interpolated to a uniform 0.5-kyr

356 sampling spacing, and set to a common mean and common standard deviation. The stack

357 is the arithmetic mean at each 0.5-kyr data step (Fig. 9a).

358 The lacustrine records included in the 0-45 ka stack from outside the Iberian

359 Margin (Table 2) are the Lac du Bouchet (France) record of Thouveny et al. (1993), the

360 Lake Biwa (Japan) record of Hayashida et al (2007), the Lake Potrok Aike (Patagonia)

361 record of Lisé-Pronovost et al. (2013), the Lake Van (Turkey) record of Vigliotti et al.

362 (2014), and the Lake Towuti (Indonesia) record of Kirana et al. (2018). Lisé-Pronovost

363 et al. (2013) offered a “corrected” NRM/ARM RPI proxy record, designed to compensate

364 for the influence on RPI of magnetic grain-size changes. The correction method was

365 originally applied to NRM/IRM data from Lake Pepin (Brachfeld and Banerjee, 2000),

366 and has rarely been used since. We utilize the Potrok Aike RPI record before "correction”

367 because we have concerns about the veracity of the correction, particularly for

368 NRM/ARM data. Age models for lacustrine RPI data incorporated in the stack are as

369 published, and are based on radiocarbon, tephrochronology, and for Lake Van,

370 correlation of XRF core-scanning records to ice-core chronologies.

371 The marine RPI records included in the 0-45 ka stack from outside the Iberian

372 Margin (Table 2) are the Black Sea record of Nowaczyk et al. (2013), the Rockall Trough 
373 record of Channell et al. (2016), the ODP Site 1063 record of Channell et al. (2012), the 374 Bermuda Rise record of Schwartz et al. (1996), the Philippine Sea record of Stott et al. 375 (2002), the ODP Site 1089 (South Atlantic) record of Stoner et al. (2003), and the Scotia 376 Sea record of Xiao et al. (2016). Age models are as published apart from the ODP Site 3771063 age model where a single additional age-depth point has been added to the 378 published age model (Channell et al., 2012). Age models are based on combinations of 379 orbitally-tuned oxygen isotope data, radiocarbon, tephrochronology and correlation to 380 ice-core chronologies.

381 For the stack from outside the Iberian Margin, the 12 records were interpolated to 382 a uniform 0.5-kyr sampling spacing, and set to a common mean and common standard 383 deviation. The stack is the mean at each 0.5-kyr time-step, giving equal weight to each of 384 the twelve records (Fig. 9a).

$385 \quad$ Finally an overall stack (Fig. 9a) was constructed by combining the individual 386 records from outside the Iberian Margin with a stack of all 10 JC089 records, the 387 Portuguese Margin Stack of Thouveny et al. (2004) and the MD01-2444 record of 388 Channell et al. (2013), giving equal weight to each record. Again, all records are on their 389 individual (published) age models, with no age adjustments (apart from a single extra age 390 tie-point for Site 1063) or record matching.

\section{Discussion}

393 Individual RPI records in the SW Iberian Margin stack (Fig. 9b) and in the stack 394 from outside the Iberian Margin (Fig. 9c) show considerable variability. Age model 395 discrepancies account for some of this variability, and the saw-tooth character of some of 396 individual records reflects low resolution at the 0.5 kyr sampling step. Rather than 397 emphasizing individual higher resolution records, we assign equal weight to each record 398 in the two stacks, and construct an overall stack as described above, that comprises a 399 combination of three Iberian Margin records and 12 records from outside the Iberian 400 Margin. The resulting stacks are similar to one another (Fig. 9a), but are very different 401 from the published stacks for this time interval (Fig. 1a). The Holocene part of the RPI 402 stacks can be only broadly matched to the Holocene compilations, CALS10k.1b and 403 SHA.DIF.14k of Korte et al. (2011) and Pavon-Carrasco et al. (2014) (Fig. 9a). The 
404 scaling of the stacks to VADM was accomplished by matching the stacks to CALS10k.1b 405 and SHA.DIF.14k and assuming a VADM of $\sim 3 \times 10^{22} \mathrm{Am}^{2}$ for the Laschamp RPI 406 minimum (Fig. 9a). The pre-Holocene part of the RPI stacks are characterized by a RPI 407 shoulder (notch) at $\sim 13-14 \mathrm{ka}$, that is represented in some individual records by a RPI 408 minima (Figs. 9 b,c), and is preceded by a RPI high at $\sim 15-18$ ka (Fig. 9a). The decrease 409 in RPI from $\sim 20 \mathrm{ka}$ to the Laschamp excursion at $\sim 41 \mathrm{ka}$ is marked by two poorly defined 410 minima at $26-30 \mathrm{ka}$ and $34 \mathrm{ka}$. These RPI minima occur in some individual records, 411 and are smoothed by the stacking process. In one of the cores included in the stack from 412 outside the Iberian Margin (Core MD04-2822 from Rockall Trough), a directional 413 excursion was recorded within a RPI minimum at $26.5 \mathrm{ka}$ (Channell et al., 2016). 414 Previously published estimates of geomagnetic field intensity (VADM) since 30 415 ka from Greenland ${ }^{36} \mathrm{Cl}$ and ${ }^{10} \mathrm{Be}$ records, and from estimated atmospheric ${ }^{14} \mathrm{C}$ 416 concentrations (Muscheler et al., 2005) do not resemble one another (Fig. 1b) or 417 previously published RPI stacks (Fig. 1a), or the stacks resolved here (Fig. 9a). The 418 resemblance amongst the previously published cosmogenic-based estimates of VADM is 419 improved prior to $30 \mathrm{ka}$ (Fig. 1b), possibly because cosmogenic isotope production is 420 more sensitive to low field intensity, and is relatively insensitive to field intensities higher 421 than modern (Masarik and Beer, 2009).

422 The peak in RPI stacks at 15-18 ka (Fig. 9a) may partially explain the well423 documented drop in atmospheric $\Delta^{14} \mathrm{C}$ in the "mystery interval" at 17.5-14.5 kyr 424 (Broecker and Barker, 2007). The apparent lag of a peak in RPI at $\sim 15-18$ ka relative to 425 the peak VADM at $14.5 \mathrm{ka}$ inferred from ${ }^{14} \mathrm{C}$ production (Fig. 10) may be attributable to 426 lock-in delay in acquisition of the remanent magnetization, with a $\sim 2$ kyr lag at a 10-15 $427 \mathrm{~cm} /$ kyr sedimentation rate being equivalent to $\sim 20-30 \mathrm{~cm}$ lock-in depth. On the other 428 hand, no such offset is observed at the Laschamp excursion where ages from lavas and 429 sediments agree rather well (e.g., Laj et al., 2014). Immediately after the RPI high at $\sim 15-$ $43018 \mathrm{ka}$, a RPI minimum at $\sim 13.5 \mathrm{ka}$ is observed in some individual records (Fig. 9), 431 notably in Core MD01-2444 where it is accompanied by a directional magnetic excursion 432 (Channell et al., 2013). This excursion has not been observed elsewhere, and it is not 433 present in any of the JC089 cores, although an excursion of similar age from ${ }^{40} \mathrm{Ar} /{ }^{39} \mathrm{Ar}$ 
434 methods (at $\sim 17 \mathrm{ka}$ ) has been documented in the Tianchi Volcanics in China (Singer et 435 al., 2014).

436 The new overall VADM stack from Figure 9a, combined with the CALS10k.1b 437 model for the Holocene (Korte et al., 2011), is now compared with updated calculations 438 of VADM from Intcal13 atmospheric ${ }^{14} \mathrm{C}$ (Reimer et al., 2013) and Greenland ${ }^{10} \mathrm{Be}$ using 439 a current Greenland ice core timescale (Svensson et al., 2008). The updated VADM 440 calculation based on ${ }^{10} \mathrm{Be}$ (Fig. 10a), using recent ${ }^{10} \mathrm{Be}$ production models (Poluianov et 441 al., 2016; Herbst et al., 2017), is different from those shown in Figure 1b (from 442 Muscheler at al., 2005) since the timescale update results in corresponding revisions in 443 accumulation rates and ${ }^{10} \mathrm{Be}$ flux. Here we based the ${ }^{10} \mathrm{Be}$ flux calculation on the average 444 GRIP and GISP2 ${ }^{10}$ Be record (Muscheler at al., 2005) and adjusted the accumulation rate 445 and ${ }^{10} \mathrm{Be}$ flux to be consistent with the most recent Greenland ice core timescale 446 (Svensson et al., 2008). This procedure may lead to a significant climate signal in the

$447{ }^{10}$ Be flux (e.g., Adolphi et al., 2014), however; it is not clear how such potential climate 448 influence can be identified and corrected over longer timescales. The new calculations 449 indicate that although the ${ }^{10} \mathrm{Be}$-based VADM fits rather well with the overall VADM 450 stack, the ${ }^{14} \mathrm{C}$-based VADM does not (Fig. 10), presumably due to changes in carbon 451 cycling over the last Termination and probably also due to an underestimated ${ }^{14} \mathrm{C}$ 452 production rate. Nevertheless, the overall VADM stack can explain the atmospheric ${ }^{14} \mathrm{C}$ 453 trend from about 25 to $15 \mathrm{ka}$ as indicated by the similar trends in the VADM stack and $454{ }^{14} \mathrm{C}$-based geomagnetic field during this period (Fig. 10).

456 8. Conclusions

457 Based on 24 sedimentary RPI records from the SW Iberian Margin and elsewhere 458 (Tables 1 and 2), we make the case for a revised view of geomagnetic field intensity in 459 the latest Pleistocene (10-30 ka). We construct a stack of RPI data from 10 sediment 460 cores recovered during Cruise JC089 (Table 1). This stack is combined with two 461 previously published records from the Iberian Margin (Thouveny et al., 2004; Channell et 462 al., 2013) and with 12 RPI records from outside the Iberian margin (Table 2) to produce 463 an overall RPI stack (Fig. 9a). The RPI stacks feature a high in RPI at $\sim 15-18$ ka that is 464 followed by a shoulder (notch) at $13-15 \mathrm{ka}$ as RPI decreases to a minimum at $\sim 9 \mathrm{ka}$. In 
465 some individual records (Fig. 9), the notch at 13-15 ka is manifest as a low in RPI that is

466 largely smoothed out by stacking. In one record, MD01-2444 (Table 2), a RPI low at 13.5

$467 \mathrm{ka}$ is associated with a directional magnetic excursion (Channell et al., 2013).

468 The overall stack indicates a progressive increase in RPI from the low in RPI at

$469 \sim 41 \mathrm{ka}$ associated with the Laschamp magnetic excursion to a high at 15-18 ka

470 corresponding to late HS1 (Fig. 10). A low in RPI at $\sim 34 \mathrm{ka}$, associated with the Mono

471 Lake magnetic excursion, and at $\sim 26-30 \mathrm{ka}$ are manifest by more pronounced RPI

472 minima in some individual records. A prominent RPI minimum at $26.5 \mathrm{ka}$ is

473 accompanied by a directional excursion in the Rockall Trough record (Table 2, Channell

474 et al., 2016).

475 The inconsistent picture of RPI in the 10-30 ka interval from published RPI stacks

476 (Fig. 1a) is attributed to poor preservation of recovered sediment in the uppermost part of

477 sediment sequences, particularly those recovered by Calypso cores and the APC used by

478 ODP/IODP. The cores incorporated into our stacks are not immune to drilling

479 disturbance, but we minimize disturbance by preferentially selecting cores recovered

480 using conventional piston and Kasten (gravity) coring, and cores with mean

481 sedimentation rates $>15 \mathrm{~cm} / \mathrm{kyr}$.

482 The new overall RPI stack is supported by a revised calculation of VADM from

483 Greenland ${ }^{10}$ Be flux (Fig. 10) using a recent ice-core timescale (Svensson et al., 2008)

484 although a possible climate influence on the ${ }^{10} \mathrm{Be}$ flux is hard to assess. The overall RPI

485 stack is, on the other hand, inconsistent with the estimated VADM from atmospheric ${ }^{14} \mathrm{C}$

486 (Fig. 10). The new overall RPI stack, even with 2 kyr magnetization lock-in delay, cannot

487 explain atmospheric ${ }^{14} \mathrm{C}$ levels (Reimer et al., 2013), not only during the "Mystery

488 Interval" but also back to $45 \mathrm{ka}$ although it can explain the atmospheric ${ }^{14} \mathrm{C}$ trend from

$489 \sim 25$ to $15 \mathrm{ka}$ (Fig. 11). An increase in marine radiocarbon ventilation in late HS1 and/or

490 the onset of the Bølling-Allerød has been observed in numerous records (e.g. Skinner and

491 Shackleton, 2004; Robinson et al., 2005; Skinner et al., 2010, 2014, 2015; Burke and

492 Robinson, 2012; Chen et al., 2015; de la Fuente et al., 2015; Umling and Thunell, 2017).

493 If the timing of the observed RPI maximum is accurate, at $\sim 15-18 \mathrm{ka}$ (Fig. 10), this

494 would raise the bar for the magnitude of marine radiocarbon ventilation change that

495 would be needed to fully account for the atmospheric $\Delta^{14} \mathrm{C}$ record, as it would imply an 
496 increasing trend in radiocarbon production while atmospheric radiocarbon activity was

497 decreasing. Offsets between observed atmospheric $\Delta^{14} \mathrm{C}$ changes and modeled

498 atmospheric $\Delta^{14} \mathrm{C}$ changes (e.g. derived from ${ }^{10} \mathrm{Be}$ - or RPI-based reconstructions of

499 variable radiocarbon production rates, using an ocean outcrop-diffusion box-model), can

500 provide an indication of how much atmospheric $\Delta^{14} \mathrm{C}$ variability might be attributed to

501 carbon cycle changes rather than ${ }^{14} \mathrm{C}$ production rate changes (Figure 11a). Across the

502 deglaciation, these offsets track atmospheric $\mathrm{CO}_{2}$ closely (Figure 11c), and share many

503 features with available marine radiocarbon ventilation records, suggesting an ocean

504 ventilation influence on atmospheric $\Delta^{14} \mathrm{C}$ and $\mathrm{CO}_{2}$. However, it is also notable that the

505 existing marine radiocarbon ventilation records exhibit smaller changes than would seem

506 to be required to fully reconcile the observed atmospheric $\Delta^{14} \mathrm{C}$ record and the revised

$507{ }^{10} \mathrm{Be}$ and RPI records (Figure 11b). Therefore, while several independent records strongly

508 support the combined influence of ocean ventilation and ${ }^{14} \mathrm{C}$ production changes on

509 atmospheric $\Delta^{14} \mathrm{C}$ and $\mathrm{CO}_{2}$ during the last ice age and over the last Termination, a

510 complete solution to the mystery of deglacial radiocarbon and carbon cycling remains

511 elusive.

512

513 Acknowledgments

514 The overall RPI stack, scaled to VADM, is in Table S1. The ${ }^{10} \mathrm{Be}$-based estimate

515 of geomagnetic field intensity is in Table S2. This work was made possible by NERC

516 support (NE/J00653X/1) for Cruise 089 aboard the RSS James Cook that permitted

517 collection of the cores for this study. JETC acknowledges support from US NSF grants

518 EAR-1014506 and OCE-0850413, LCS from UK NERC grant NE/L006421/1, and RM

519 from Swedish Research Council grant DNR2013-8421. We thank Kainian Huang for

520 laboratory assistance, Nicolas Thouveny, Agathe Lisé-Pronovost, Wenshen Xiao and

521 Kartika Kirana for sending requested data, and Claude Hillaire-Marcel for editorial

522 guidance. 
Acton, G.D., M. Okado, B.M. Clement, S.P. Lund and T. Williams, Paleomagnetic overprints in ocean sediment cores and their relationship to shear deformation caused by piston coring. J. Geophys. Res., 107, B4, 2067, 10.1029/2001JB000518, 2002. Adolphi, F., R. Muscheler, A. Svensson, A. Aldahan, G. Possnert, J. Beer, J. Sjolte, S. Bjorck, K. Matthes and R. Thiéblemont, Persistent link between solar activity and Greenland climate during the Last Glacial Maximum. Nature Geoscience 7, 662-666, 2014.

Bard, E., F. Rostek, and G. Menot-Combes, Radiocarbon calibration beyond 20,000 ${ }^{14} \mathrm{C}$ yr B.P. by means of planktonic foraminifera of the Iberian Margin. Quaternary Research, 61, 204-214, 2004.

Baumgartner, S., J. Beer, J. Masarik, G. Wagner, L. Meynadier, H.-A. Synal, Geomagnetic modulation of the ${ }^{36} \mathrm{Cl}$ flux in the GRIP ice core, Greenland. Science 279,1330-1332, 1998.

Beck, J.W., D.A. Richards, R.L. Edwards, B.W. Silverman, P.L. Smart, D.J. Donahue, S. Hererra-Osterheld, G.S. Burr, L. Calsoyas, A.J.T. Jull, D. Biddulph, Extremely large variations of atmospheric $14 \mathrm{C}$ concentration during the last glacial period, Science 292, 2453-2458, 2001.

Brachfeld, S., and S.K. Banerjee, A new high-resolution geomagnetic paleointensity record for the North American Holocene: a comparison of sedimentary and absolute intensity data. J. Geophys. Res. 105 (B1), 821-834, 2000.

Broecker, W. and S. Barker, A $190 \%$ drop in atmospheric $\Delta^{14} \mathrm{C}$ during the "Mystery Interval" (17.5-14.5 kyr). Earth Planet Sci. Letters, 256, 90-99, 2007.

Bronk Ramsey, C., et al., A complete terrestrial radiocarbon record for 11.2 to $52.8 \mathrm{kyr}$ B.P., Science 338, 370, 2012.

Burke, A. and L.F. Robinson, The Southern Ocean's role in carbon exchange during the last deglaciation. Science 335, 557-561, 2012.

Carcaillet, J.T., D. L. Bourles, N. Thouveny and M. Arnold, A high resolution authigenic 10Be/9Be record of geomagnetic moment variations over the last $300 \mathrm{ka}$ from sedimentary cores of the Portuguese margin. Earth and Planetary Science Letters 219 (2004) 397-412, 2004.

Carter-Stiglitz, B., B. Moskowitz and M. Jackson, Unmixing magnetic assemblages and the magnetic behavior of bimodal mixtures. J. Geophys. Res., 106, 26,397-26, 411, 2001.

Channell, J.E.T., Xuan, C. and Hodell, D.A., Stacking paleointensity and oxygen isotope data for the last 1.5 Myrs (PISO-1500). Earth Planet. Sci. Letters, 283, 14-23, 2009.

Channell, J.E.T., D.A. Hodell and J.H. Curtis, ODP Site 1063 (Bermuda Rise) revisited: oxygen isotopes, excursions and paleointensity in the Brunhes Chron. Geochem. Geophys. Geosyst. $\left(G^{3}\right)$, 13(1), Q02001, doi:10.1029/2011GC003897, 27 pp., 2012. Channell, J.E.T., D.A. Hodell, V. Margari, L.C. Skinner, P.C. Tzedakis, and M.S. Kesler, Biogenic magnetite, detrital hematite, and relative paleointensity in sediments from the Southwest Iberian Margin, Earth Planet. Sci. Letters, 376, 99-109, 2013.

Channell, J. E. T., R. J. Harrison, I. Lascu, I. N. McCave, F. D. Hibbert, and W. E. N. Austin, Magnetic record of deglaciation using FORC-PCA, sortable-silt grain size, and magnetic excursion at $26 \mathrm{ka}$, from the Rockall Trough (NE Atlantic), Geochem. 
569

570

571

572

573

574

575

576

577

578

579

580

581

582

583

584

585

586

587

588

589

590

591

592

593

594

595

596

597

598

599

600

601

602

603

604

605

606

607

608

609

610

611

612

613

614

Geophys. Geosyst., 17, 1823-1841, doi:10.1002/2016GC006300, 2016.

Chen, T., L.F. Robinson, A. Burke, J. Southon, P. Spooner, P.J. Morris and H.C. Ng, Synchronous centennial abrupt events in the ocean and atmosphere during the last deglaciation. Science 349, 1537-1541, 2015.

Day, R., M. Fuller, and V.A. Schmidt, Hysteresis properties of titanomagnetites: grainsize and compositional dependence. Phys. Earth Planet. Int., 13, 260-267, 1977.

Deplazes, G., A. Lückge, L.C. Peterson, A. Timmermann, Y. Hamann, K.A. Hughen, U. Röhl, C. Laj, M.A. Cane, D.M. Sigman, and G.H. Haug, Links between tropical rainfall and North Atlantic climate during the last glacial period, Nature Geoscience 6, 213-217, 2013.

de la Fuente, M., L. Skinner, E. Calvo, C. Pelejero and I. Cacho, Increased reservoir ages and poorly ventilated deep waters inferred in the glacial Eastern Equatorial Pacific. Nat Comm., 6, 2015.

Dunlop, D.J., Theory and application of the Day plot (Mrs/Ms versus $\mathrm{Hcr} / \mathrm{Hc}) 1$. Theoretical curves and tests using titanomagnetite data. J. Geophys. Res., 107, B3, 2056, doi:10.1029/2001JB000486, 2002.

Dunlop, D.J. and B. Carter-Stiglitz, Day plots of mixtures of superparamagnetic, single domain, pseudosingle domain, and multidomain magnetites. J. Geophys. Res., 111, B12S09, doi: 10.1029/2006JB004499, 2006.

Fairbanks, R.G., R.A. Mortlock, T.-C. Chiu, L. Cao, A. Kaplan, T.P. Guilderson, T.W. Fairbanks, A.L. Bloom, P.M. Grootes, M.-J. Nadeau, Radiocarbon calibration curve spanning 0 to $50,000 \mathrm{yr}$ BP based on paired $230 \mathrm{Th} / 234 \mathrm{U} / 238 \mathrm{U}$ and $14 \mathrm{C}$ dates on pristine corals, Quat. Sci. Rev. 24, 1781-1796, 2005.

Finkel, R.C., and K. Nishiizumi, Beryllium-10 concentrations in the Greenland ice sheet project 2 ice core from 3-40 ka. J. Geophys. Res., 102, 26699-26706, 1997.

Freeman, E., L. C. Skinner, C. Waelbroeck, and D. A. Hodell, Radiocarbon evidence for enhanced respired carbon storage in the Atlantic at the Last Glacial Maximum. Nature Geoscience, 7, 11998, DOI: 10.1038/ncomms11998

|www.nature.com/naturecommunications, 2016.

Genevey, A., Y. Gallet, C. G. Constable, M. Korte, and G. Hulot, ArcheoInt: An upgraded compilation of geomagnetic field intensity data for the past ten millennia and its application to the recovery of the past dipole moment, Geochem. Geophys. Geosyst., 9, Q04038, doi:10.1029/2007GC001881, 2008.

Hayashida, A., A. Mohammed, Y. Kuniko, H. Kitagawa, M. Torii and K. Takemura, Environmental magnetic record and paleosecular variation data for the last $40 \mathrm{kyrs}$ from Lake Biwa sediments, Central Japan. Earth Planets Space, 59, 807-814, 2007.

Herbst, K., R. Muscheler and B. Heber, The new local interstellar spectra and their influence on the production rates of the cosmogenic radionuclides ${ }^{10} \mathrm{Be}$ and ${ }^{14} \mathrm{C}$. J. Geophys. Res., Space Physics 122, 23-34, doi:10.1002/2016JA023207, 2017.

Hodell, D.A., Crowhurst, S., Skinner, L., Tzedakis, P.C., Margari, V., Channell, J.E.T., Kamenov, G., Maclachlan, S., and Rothwell, G., Response of Iberian Margin sediments to orbital and suborbital forcing over the past $420 \mathrm{ka}$. Paleoceanography, 28, 1-15, doi:10.1002/palo.20017, 2013.

Hodell, D.A., Elderfield, H., Greaves, M., McCave, I.N., Skinner, L., Thomas, A., White, N., and the JC089 Scientific Party, JC089 Cruise Report - IODP Site Survey of the Shackleton Sites, SW Iberian Margin, British Ocean Data Centre, 
615

616

617

618

619

620

621

622

623

624

625

626

627

628

629

630

631

632

633

634

635

636

637

638

639

640

641

642

643

644

645

646

647

648

649

650

651

652

653

654

655

656

657

658

659

https://www.bodc.ac.uk/data/information_and_inventories/cruise_inventory/report/1 3392/, 2014.

Hodell, D. A., L. Lourens, S. J. Crowhurst, T. Konijnendijk, R. Tjallingii, F. JimenezEspejo, L. C. Skinner, P. C. Tzedakis, and Members of the Shackleton Site Project, 2015. A reference time scale for Site U1385 (Shackleton Site) on the Iberian Margin, Global Planetary Change, 133: 9-64, 2015.

Hughen, K., S. Lehman, J. Southon, J. Overpeck, O. Marchal, C. Herring, J. Turnbull, ${ }^{14} \mathrm{C}$ activity and global carbon cycle changes over the past 50,000 yr. Science 303 , 202-207, 2004.

King, J.W., S.K. Banerjee, and J. Marvin, A new rock-magnetic approach to selecting sediments for geomagnetic paleointensity studies: application to paleointensity for the last 4000 years. J. Geophys. Res. 88 (1983) 5911-5921, 1983.

Kirana, K.H., S. Bijaksana, J. King, G.H. Tamuntuan, J. Russell, L. O. Ngkoimani, D. Dahrin, and S.J. Fajar, A high-resolution, 60 kyr record of relative geomagnetic field intensity from Lake Towuti, Indonesia. Phys. Earth Planet. Int., 275, 9-18, 2018.

Kirschvink, J.L., The least squares lines and plane analysis of paleomagnetic data. Geophys. J.R. Astr. Soc. 62, 699-718, 1980.

Korte, M., F. Donadini, and C. Constable, Geomagnetic field for 0-3 ka: 2. Revised global time-varying models, Geochem. Geophys. Geosyst., 10, Q06008, doi:10.1029/2008GC002297, 2009.

Korte, M., C. Constable, F. Donadini, and R. Holme, Reconstructing the Holocene geomagnetic field, Earth Planet. Sci. Lett., 312, 497-505, 2011.

Laj, C., C. Kissel, A. Mazaud, J.E.T. Channell, and J. Beer, North Atlantic paleointensity stack since $75 \mathrm{ka}$ (NAPIS-75) and the duration of the Laschamp event. Phil. Trans. Royal Soc. London, 358, 1009-1025, 2000.

Laj, C., C. Kissel and J. Beer, High-resolution global paleointensity stack since $75 \mathrm{kyr}$ (GLOPIS-75) calibrated to absolute values. In: Timescales of the Paleomagnetic Field. J.E.T. Channell, D.V. Kent, W. Lowrie and J.G. Meert (editors), Geophysical Monograph 145, American Geophysical Union, Washington DC, 255-265, 2004.

Laj, C., H. Guillou and C. Kissel, Dynamics of the Earth's magnetic field in the 10-75 kyr period comprising the Laschamp and Mono Lake excursions: New results from the French Chaine des Puys in a global perspective. Earth Planet. Sci. Letters, 387, 184-197, 2014.

Laj, C., and J.E.T. Channell, Geomagnetic excursions. In: Treatise on Geophysics: Volume 5, Geomagnetism (editor: M. Kono). Chapter 10, 343-383, Elsevier, Amsterdam, 2015.

Lemieux-Dudon, B., E. Blayo, J.R. Petit, C. Waelbroeck, A. Svensson, C. Ritz, J.-M. Barnola, B.M. Narcisi and F. Parrenin, Consistent dating for Antarctic and Greenland ice cores. Quat. Sci. Rev. 29, 8-20, 2010.

Levi, S., and S.K. Banerjee, On the possibility of obtaining relative paleointensities from lake sediments. Earth Planet. Sci. Letters, 29, 219-226, 1976.

Lisé- Pronovost, A. G. St-Onge, C. Gogorza, T. Haberzetti, M. Preda, P. Kliem, P. Francus and B. Zolitschka, The PASADO Science Team, High-resolution paleomagnetic secular variations and relative paleointensity since the Late Pleistocene in southern South America. Quat. Sci. Rev., 71, 91-108, 2013. 
660

661

662

663

664

665

666

667

668

669

670

671

672

673

674

675

676

677

678

679

680

681

682

683

684

685

686

687

688

689

690

691

692

693

694

695

696

697

698

699

700

701

702

703
Masarik, J. and J. Beer, Simulation of particle fluxes and cosmogenic nuclide production in the Earth's atmosphere. J. Geophys. Res., 104, 12,099-12,111, 1999.

Masarik, J. and J. Beer, An updated simulation of particle fluxes and cosmogenic nuclide production in the Earth's atmosphere. J. Geophys. Res., 114, doi:10.1029/2008JD010557, 2009.

Ménabréaz, L., N. Thouveny, D.L. Bourles, P. Deschamps, B. Hamelin and F. Demory, The laschamp geomagnetic dipole low expressed as a cosmogenic ${ }^{10} \mathrm{Be}$ atmospheric overproduction at $\sim 41$ ka. Earth Planetary Science letters, 312, 305-317, 2011.

Monnin, E., A. Indermuhle, A. Dallenbach, J. Fluckiger, B. Stauffer, T.F. Stocker, D. Raynaud and J.M. Barnola, Atmospheric $\mathrm{CO}_{2}$ concentrations over the Last Glacial Termination. Science 291, 112-114, 2001.

Moreno, E., N. Thouveny, D. Delanghe, I.N. McCave and N.J. Shackleton, Climatic and oceanographic changes in the Northeast Atlantic reflected by magnetic properties of sediments deposited on the Portuguese Margin during the last $340 \mathrm{ka}$. Earth and Planetary Sci. Letters, 202, 465-480, 2002.

Muscheler, R., J. Beer, G. Wagner, C. Laj, C. Kissel, G. M. Raisbeck, F. Yiou, and P.W. Kubik, Changes in the carbon cycle during the last deglaciation as indicated by the comparison of ${ }^{10} \mathrm{Be}$ and ${ }^{14} \mathrm{C}$ records. Earth and Planet. Sci. Letters, 219, 325-340, 2004.

Muscheler, R., J. Burg, P.W. Kubik and H.A. Synal, Geomagnetic field intensity during the last 60,000 years based on ${ }^{10} \mathrm{Be}$ and ${ }^{36} \mathrm{Cl}$ from the Summit ice cores and ${ }^{14} \mathrm{C}$. Quat. Sci. Revs., 24, 1849-1860, 2005.

Nowaczyk, N.R., U. Frank, J. Kind and H.W. Arz, A high-reolution paleointnesity stack of the past 14 to $68 \mathrm{ka}$ from Black Sea sediments. Earth Planet. Sci. Lett., 384, 1-16, 2013.

Pavon-Carrasco, F.J., M.L. Osete and J.M. Torta and A. De Santis, A geomagnetic field model for the Holocene based on archaeomagnetic and lava flow data. Earth Planet. Sci. Lett., 388, 98-109, 2014.

Peterson, L.C., G.H. Haug, K.A. Hughen and U. Röhl, Rapid changes in the hydrologic cycle of the tropical Atlantic during the Last Glacial, Science 290, 1947-1951, 2000.

Poluianov, S.V., G.A. Kovaltsov, A.L. Mishev and I.G. Usoskin, Production of cosmogenic isotopes $7 \mathrm{Be}, 10 \mathrm{Be}, 14 \mathrm{C}, 22 \mathrm{Na}$, and $36 \mathrm{Cl}$ in the atmosphere: Altitudinal profiles of yield functions. J. Geophys. Res. Atmos. 121, 8125-8136, doi:8110.1002/2016JD025034, 2016.

Pressling, N., C. Laj, C. Kissel, D. Champion and D. Gubbins, Palaeomagnetic intensities from ${ }^{14} \mathrm{C}$-dated lava flows on the Big Island, Hawaii: 0-21 kyr. Earth Planet. Sci. Letters, 247, 26-40, 2006.

Reimer, P. et al., IntCal13 and Marine13 radiocarbon age calibration curves 0-50,000 years cal BP. Radiocarbon 55, 4, 1869-1887, 2013.

Roberts, A.P., L. Chang, D. Heslop, F. Florindo and J.C. Larrasoana, Searching for single domain magnetite in the "pseudo-single-domain" sedimentary haystack: Implications of biogenic magnetite preservation for sediment magnetism and relative paleointensity determinations. J. Geophys. Res., 117, B08104, doi:10.1029/2012JB009412, 2012. 
704

705

706

707

708

709

710

711

712

713

714

715

716

717

718

719

720

721

722

723

724

725

726

727

728

729

730

731

732

733

734

735

736

737

738

739

740

741

742

743

744

745

746

747

748

749

Robinson, L.F., J.F. Adkins, L.D. Keigwin, J. Southon, D.P. Fernandez, S.-L.Wang and D.S. Scheirer, Radiocarbon variability in the western North Atlantic during the last deglaciation. Science, 310, 1469-1473, 2005.

Schwartz, M., S.P. Lund and T.C. Johnson, Environmental factors as complicating influences in the recovery of quantitative geomagnetic field paleointensity estimates from sediments. Geophys. Res. Lett., 23, 2693-2696, 1996.

Shackleton, N.J., M.A. Hall, and E. Vincent, Phase relationships between millennialscale events 64,000-24,000 years ago. Paleoceanography 15, 565-569, 2000.

Shackleton, N.J., R.G. Fairbanks, T.-C. Chiu, and F. Parrenin, Absolute calibration of the Greenland time scale: implications for Antarctic time scales and for $\Delta^{14} \mathrm{C}$. Quat. Sci. Rev. 23, 1513-1522, 2004.

Siegenthaler, U., Uptake of excess $\mathrm{CO}_{2}$ by an outcrop-diffusion model ocean. J. Geophys. Res., 88, 3599-3608, 1983.

Simon, Q., N. Thouveny, D. L. Bourlès, J.-P. Valet, F. Bassinot, L. Ménabréaz, V. Guillou, S. Choy, and L. Beaufort, Authigenic ${ }^{10} \mathrm{Be} /{ }^{9} \mathrm{Be}$ ratio signatures of the cosmogenic nuclide production linked to geomagnetic dipole moment variation since the Brunhes/Matuyama boundary, J. Geophys. Res. Solid Earth, 121, doi:10.1002/2016JB013335, 2016.

Singer, B. S., B. R. Jicha, H. He, and R. Zhu, Geomagnetic field excursion recorded 17 ka at Tianchi Volcano, China: New ${ }^{40} \mathrm{Ar} /{ }^{39} \mathrm{Ar}$ age and significance, Geophys. Res. Lett., 41, 2794-2802,doi:10.1002/2014GL059439, 2014.

Skinner, L.C., and I.N. McCave, Analysis and modeling of gravity and piston coring based on soil mechanics. Marine Geology, 199, 181-204, 2003.

Skinner, L.C., N.J. Shackleton and H. Elderfield, Millennial-scale variability of deepwater temperature and $\delta^{18} \mathrm{O}_{\mathrm{dw}}$ indicating deep-water source variations in the Northeast Atlantic, 0-34 cal. ka BP. Geochem. Geophys. Geosys. 4, 1-17, 2003.

Skinner, L.C. and N.J. Shackleton, Rapid transient changes in Northeast Atlantic deepwater ventilation-age across Termination I. Paleoceanography 19, 1-11, 2004.

Skinner, L.C., H. Elderfield and M. Hall, Phasing of millennial events and Northeast Atlantic deep-water temperature change since $\sim 50 \mathrm{ka} \mathrm{BP}$, in: Schmittner, A., Chiang, J., Hemming, S.R. (Eds.), Ocean Circulation: Mechanisms and Impacts. AGU Monograph, pp. 197-208, 2007.

Skinner, L.C., S. Fallon, C. Waelbroeck, E. Michel and S. Barker, Ventilation of the deep Southern Ocean and deglacial CO2 rise. Science 328, 1147-1151, 2010.

Skinner, L.C., C. Waelbroeck, A. Scrivner and S. Fallon, Radiocarbon evidence for alternating northern and southern sources of ventilation of the deep Atlantic carbon pool during the last deglaciation. Proc. Nat. Acad. Sci., 111, 5480-5484, 2014.

Skinner, L., I.N. McCave, L. Carter, S. Fallon, A. Scrivner and F. Primeau, Reduced ventilation and enhanced magnitude of the deep Pacific carbon pool during the last glacial period. Earth Planet. Sci. Lett. 411, 45-52, 2015.

Southon, J., A.L., Noronha, H. Cheng, R.L. Edwards and Y. Wang, A high-resolution record of atmospheric ${ }^{14} \mathrm{C}$ based on Hulu Cave speleothem H82. Quaternary Science Reviews 33, 32-41, doi:https://doi.org/10.1016/j.quascirev.2011.11.022, 2012.

Stoner, J.S., C. Laj, J.E.T. Channell and C. Kissel. South Atlantic (SAPIS) and North Atlantic (NAPIS) geomagnetic paleointensity stacks ( $0-80 \mathrm{ka})$ : implications for interhemispheric correlation. Quaternary Science Reviews, 21, 1141-1151, 2002. 
758

759

760

761

762

763

764

765

766

767

768

769

770

771

772

773

774

775

776

777

778

779

780

781

782

783

784

785

786

787

788

789

790

791

792

793

794

795
Stoner, J.S., J.E.T. Channell, D. A. Hodell and C. Charles. A 580 kyr paleomagnetic record from the sub-Antarctic South Atlantic (ODP Site 1089). J. Geophys. Res., 108, 2244, doi:10.1029/2001JB001390, 2003.

Stott, L., C. Poulsen, S. Lund and R. Thunell, Super ENSO and global climate oscillations at millennial timescles. Science, 297, 222-226, 2002.

Svensson, A. et al., A 60000 year Greenland stratigraphic ice core chronology. Climate of the Past 4, 47-57, doi:10.5194/cp-4-47-2008, 2008.

Széréméta, N., F. Bassinot, Y. Balut, L. Labeyrie and M. Pagel, Oversampling of sedimentary series collected by giant piston corer: Evidence and corrections based on 3.5-kHz chirp profiles. Paleoceanography, 19, PA1005, doi:10.1029/2002PA000795, 2004.

Tauxe, L., Sedimentary records of relative paleointensity of the geomagnetic field: theory and practice. Rev. Geophys., 31, 319-354, 1993.

Teanby, N., C. Laj, D. Gubbins and M. Pringle, A detailed palaeointnesity and inclination record from drill core SOH1 on Hawaii. Phys. Earth Planet. Int., 131, 101-140, 2002.

Thomas, R., Y. Guyodo and J.E.T. Channell, U-channel track for susceptibility measurements. Geochemistry, Geophysics and Geosystems $\left(\mathrm{G}^{3}\right), 1050$, doi: 10.1029/2002GC000454, 2003.

Thomson, J., S. Nixon, C. P. Summerhayes, J. Schonfeld, R. Zahn, and P. Grootes, Implications for sedimentation changes on the Iberian margin over the last two glacial/interglacial transitions from $\left({ }^{230} \mathrm{Th}_{\text {excess }}\right)$ systematics, Earth Planet. Sci. Letts. 165, 255-270, 1999.

Thomson, J., S. Nixon, C. P. Summerhayes, E. J. Rohling, J. Schonfeld, R. Zahn, P. Grootes, F. Abrantes, L. Gaspar, and S. Vaqueiro, Enhanced productivity on the Iberian margin during glacial/interglacial transitions revealed by barium and diatoms, J. Geol. Soc., 157, 667-677, 2000.

Thouveny, N., K.M. Creer and D. Williamson, Geomagnetic moment variations in the last 70,000 years, impact on production of cosmogenic isotopes. Global and Planet. Change, 7, 157-172, 1993.

Thouveny, N., Carcaillet, J., Moreno, E., Leduc, G., and Nerini, D., Geomagnetic moment variation and paleomagnetic excursions since $400 \mathrm{kyr}$ BP; a stacked record from sedimentary sequences of the Portuguese margin. Earth Planet. Sci. Lett., 219: 377-396, 2004.

Umling, N.E. and R.C. Thunell, Synchronous deglacial thermocline and deep-water ventilation in the eastern equatorial Pacific. Nature Communications 8, 14203, 2017.

Yiou, F., Raisbeck, G.M., Baumgartner, S., Beer, J., Hammer, C., Johnsen, S., Jouzel, J., Kubik, P.W., Lestringuez, J., Stiévenard, M., Suter, M., Yiou, P., Beryllium-10 in the Greenland Ice Core Project ice core at Summit, Greenland. J. Geophys. Res. 102, 26783-26794, 1997.

Valet, J.-P., L. Meynadier and Y. Guyodo, Geomagnetic dipole strength and reversal rate over the past two million years. Nature 435, 802-805, 2005.

Vigliotti, L., J.E.T. Channell and M. Stockhecke, Paleomagnetism of Lake Van sediments: chronology and paleoenvironment since 350 ka. Quat. Sci. Revs., 104, 18-29, 2014.

Wagner, G., J. Beer, C. Laj, C. Kissel, J. Masarik, R. Muscheler, H.-A. Synal, Chlorine36 evidence for the Mono Lake event in the Summit GRIP ice core. Earth and 
796

797

798

799

800

801

802

803

804

805

806

807

808

809

810

811

812

813

814

815

816

817

818
Planetary Science Letters 181, 1-6, 2000.

Wang, Y.J., H. Cheng, R.L. Edwards, Z.S. An, J.Y. Wu, C.-C. Shen, J.A. Dorale, A highresolution absolute-dated Late Pleistocene monsoon record from Hulu Cave, China, Science 294, 2345-2348, 2001.

Weeks, R., C. Laj, L. Endignoux, M. Fuller, A. Roberts, R. Manganne, E. Blanchard, and $\mathrm{W}$. Goree, Improvements in long-core measurement techniques: applications in palaeomagnetism and palaeoceanography. Geophys. J. Int., 114, 651-662, 1993.

Xiao, W., T. Frederichs, R. Gersonde and G. Kuhn, Constraining the dating of late Quaternary marine sediment records from the Scotia Sea (Southern Ocean). Quat. Geochron., 31, 97-118, 2016.

Xuan, C. and J.E.T. Channell, UPmag: MATLAB software for viewing and processing uchannel or other pass-through paleomagnetic data. Geochem. Geophys. Geosyst., 10, Q10Y07, doi:1029/2009GC002584, 2009.

Xuan, C., J.E.T. Channell and D.A. Hodell, Quaternary paleomagnetic and oxygen isotope records from diatom-rich sediments of the southern Gardar Drift (IODP Site U1304, North Atlantic). Quaternary Science Reviews, 142, 74-89, 2016.

Zangger, E. and I.N. McCave, A redesigned kasten core barrel and sampling technique. Marine Geology, 94, 165-171, 1990.

Ziegler, L.B., C.G. Constable, C.L. Johnson and L. Tauxe, PADM2M: a penalized maximum likelihood model of the 0-2 Ma paleomagnetic axial dipole moment. Geophys. J. Int., 184, 1069-1089, 2011. 
819 Figure Captions

820

821 Fig. 1 (a) Relative paleointensity stacks: NAPIS (blue, Laj et al., 2000), GLOPIS (orange, 822 Laj et al., 2004), SAPIS (dark green, Stoner et al., 2003), Sint-2000 (dashed red, Valet et 823 al., 2005), PISO-1500 (dashed black, Channell et al., 2009) and PADM2M (dashed light

824 green, Ziegler et al., 2011). (b) Modeled Holocene axial dipole field intensity (brown,

825 Korte et al., 2011; black, Pavon-Carrasco et al., 2014), virtual axial dipole moment

826 (VADM) determined from ${ }^{10} \mathrm{Be}$ flux (blue) and ${ }^{36} \mathrm{Cl}$ flux (green) in Greenland ice cores

827 (Muscheler et al., 2005), and from $\Delta^{14} \mathrm{C}$ (red dashed, Muscheler et al., 2005).

828

829 Fig. 2. Location of stations (3-8) occupied during cruise JC089 (Table 1), and

830 neighboring cores (MD95-2042 and MD01-2444, Table 2). Core MD01-2444 and Station

8316 are nominally at the same location.

832

833 Fig. 3. (a) $\mathrm{Ca} / \mathrm{Ti}$ ratio from XRF core scans of piston cores (blue) and Kasten cores (red)

834 correlated to the $\mathrm{L}^{*}$ reflectance from Cariaco Basin (black) from Deplazes et al. (2013)

835 for the 0-50 ka interval. (b) $\mathrm{Ca} / \mathrm{Ti}$ ratio from XRF core scans for the 12-18 ka interval. (c)

$836 \mathrm{Zr} / \mathrm{Sr}$ ratio from XRF core scans for the 12-18 ka interval. Piston cores shown in blue,

837 Kasten cores shown in red with labeled records from core 06-4K (light green), 06-5K

838 (dark green) and 05-3K. Younger Dryas (YD), Bølling-Allerød (BA), Heinrich stadials

839 (HS1-HS5) are marked.

840

841 Fig. 4. Component declination, inclination and associated maximum angular deviation

842 (MAD) values determined for a uniform 20-80 $\mathrm{mT}$ peak field demagnetization interval.

843 Piston cores 05-3P (green) and 03-1P (black) show variable declinations in the upper

844 part. Other piston cores shown in blue, and Kasten cores in red. Cores were not oriented

845 in azimuth, and the declinations were set by uniform rotation of the mean declination for

846 each core to $0^{\circ}$.

847

848 Fig. 5 (a) Examples of orthogonal projection of AF demagnetization of natural remanent

849 magnetization (NRM) for u-channel samples from JC089 Kasten cores. Examples from 
850 piston cores are shown in Figure S7. Projections are shown for core depths of $100 \mathrm{~cm}$, $851200 \mathrm{~cm}, 250 \mathrm{~cm}$ and $350 \mathrm{~cm}$ (300 cm usually corresponds to a section break). Peak fields 852 are $0,10-30 \mathrm{mT}$ in 5mT steps, 30-60 $\mathrm{mT}$ in 2.5 $\mathrm{mT}$ steps and 60-80 $\mathrm{mT}$ in $5 \mathrm{mT}$ steps.

853 Intensities are given in $\mathrm{mA} / \mathrm{m}$. (b) Normalized intensities for NRM (black), ARM (blue),

$854 \operatorname{IRM}_{0.3 \mathrm{~T}}$ (orange), and $\mathrm{IRM}_{1 \mathrm{~T}}$ (red) at core depths of $100 \mathrm{~cm}$ and $200 \mathrm{~cm}$ in Cores $03-6 \mathrm{~K}$, $855 \quad 04-2 \mathrm{~K}$ and $05-3 \mathrm{~K}$.

856

857 Fig. 6. (a) Plot of anhysteretic susceptibility $\left(\kappa_{\text {arm }}\right)$ versus susceptibility $(\kappa)$ with lines 858 indicating lines of equal magnetite grain-size after King et al. (1983). (b) Hysteresis ratio 859 plot for JC089 piston core data (blue) and JC089 Kasten core data (red) after Day et al. 860 (1977) with magnetite grain size mixing line (green) from Carter-Stiglitz et al. (2001), 861 and data for unannealed sized magnetite (Dunlop, 2002; Carter-Stiglitz and Dunlop, 862 2006). (c) Susceptibility ( $\kappa)$ versus age for JC089 piston cores (blue) and JC089 Kasten 863 cores (red) with core $07-4 \mathrm{P}$ labeled. (d) $\kappa_{\mathrm{arm}} / \kappa$ versus age for JC089 piston cores (blue)

864 and JC089 Kasten cores (red) with cores 06-4K and 07-4P labeled. (e) S-ratios

865 determined as the ratio of $\operatorname{IRM}_{0.3 \mathrm{~T}}$ over $\operatorname{IRM}_{1 \mathrm{~T}}$ (both after AF demagnetization at peak 866 fields of $30 \mathrm{mT}$ ) for a selection of JC089 Kasten cores (red) and piston cores (blue).

867 Labeling of Younger Dryas (YD) and Heinrich stadials: see caption of Figure 3. 868

869 Fig. 7. Sedimentation rates, and relative paleointensity (RPI) proxies for Cores 06-4K, 870 06-5K and MD01-2444. Slopes and accompanying linear correlation coefficients (r):

871 NRM/ARM (dark blue), NRM/ARMAQ (light blue), NRM/IRM ${ }_{0.3 \mathrm{~T}}$ (orange),

$872 \mathrm{NRM} / \mathrm{IRM}_{1 \mathrm{~T}}$ (red). Core MD01-2444 RPI proxy (black) and sedimentation rates (red)

873 from Channell et al. (2013). Yellow shading indicates RPI minimum at $\sim 13.5 \mathrm{ka}$. Grey

874 shading indicates last $2 \mathrm{kyr}$ (unreliable surface sediment).

875

876 Fig. 8. Sedimentation rates, and relative paleointensity (RPI) proxies for (a) Cores 03-1P 877 and 03-6K, (b) Cores 04-2P and 04-2K, (c) Cores 05-3P and 05-3K, (d) Cores 07-4P and 878 08-5P. Slopes and accompanying linear correlation coefficients (r): NRM/ARM (dark 879 blue), NRM/ARMAQ (light blue), NRM/IRM ${ }_{0.3 \mathrm{~T}}$ (orange), NRM/IRM $\mathrm{IT}_{1 \mathrm{~T}}$ (red). Yellow 
880 shading indicates RPI minimum at $\sim 13.5 \mathrm{ka}$. Grey shading indicates last $2 \mathrm{kyr}$ (unreliable 881 surface sediment).

882

883 Fig. 9. Relative paleointensity data: (a) Iberian Margin stack (red), the stack from outside 884 the Iberian Margin (blue) and an overall stack (black, see text for details) with the 885 Holocene models of Korte et al. (2011) (brown) and Pavon-Carrasco et al. (2014) (black). 886 Error bars on stacks are standard errors $(2 \sigma)$. (b) Individual Iberian Margin records from 887 piston cores (blue) and Kasten cores (red) with Core MD01-2444 data (black continuous 888 line, Channell et al., 2013) and the Portuguese Margin Stack (green, Thouveny et al., 889 2004). The black dashed line represents the Iberian Margin stack. (c) Individual records 890 from outside the Iberian Margin (Table 2) including records from the South Atlantic 891 realm (red), western Pacific realm (green), North Atlantic (blue) and 892 Europe/Mediterranean (black). Black dashed line is the resulting stack for records from 893 outside the Iberian Margin. Yellow shading marks RPI minima at $\sim 13.5 \mathrm{ka}, 26.5 \mathrm{ka}$ 894 (Rockall excursion), $34 \mathrm{ka}$ (Mono Lake excursion) and $41 \mathrm{ka}$ (Laschamp excursion). 895 Grey shading indicates last 2 kyr (unreliable surface sediment).

897 Fig. 10. The overall virtual axial dipole (VADM) geomagnetic stack from Figure 9a 898 (black with $2 \sigma$ error) with the Holocene model of Korte et al. (2011) (green) plotted with 899 an updated calculation of the ${ }^{10}$ Be-based VADM (blue) and ${ }^{14} \mathrm{C}$-based VADM (red). The 900 updated VADM calculations from ${ }^{14} \mathrm{C}$ and ${ }^{10} \mathrm{Be}$, in contrast to Figure $1 \mathrm{~b}$ (from Muscheler 901 at al., 2005), are based on the most recent Greenland ice-core time scale (Svensson et al., 902 2008). The ${ }^{10} \mathrm{Be}$-based curve was calculated after low-pass filtering (cut-off 1/3000 yrs) 903 the revised ${ }^{10} \mathrm{Be}$ flux, and by using the most recent ${ }^{10} \mathrm{Be}$ production models (Poluianov et 904 al., 2016; Herbst et al., 2017).

905

906 Fig. 11 (a) Comparison of the Intcal13 ${ }^{14} \mathrm{C}$ data (black, Reimer et al., 2013) and modeled $907 \Delta^{14} \mathrm{C}$ based on the overall VADM stack (labeled PI), and the ${ }^{10}$ Be-based VADM, using a 908 box-diffusion carbon cycle model (Siegenthaler, 1983) where the solid blue curve 909 includes no magnetization lock-in delay and the dashed light blue curve includes a 2 kyr 910 lock-in delay. The conversion of geomagnetic field into ${ }^{14} \mathrm{C}$ production rates was 
911 achieved using the local interstellar cosmic ray spectrum of Herbst et al. (2017) and the

912 cosmogenic radionuclide yield functions of Poluianov et al. (2016). (b) Selected

913 published marine radiocarbon ventilation records from the North Atlantic (red line and

914 stars; Skinner et al., 2014), South Atlantic (black line and crossed diamonds; Skinner et

915 al., 2010), South Pacific (purple filled diamonds; Skinner et al., 2015), and Eastern

916 Equatorial Pacific (purple line and crossed squares; de la Fuente et al., 2015) compared

917 with the 'expected' mean ocean ventilation age derived from the observed and modeled

918 atmospheric radiocarbon activities in (a), assuming that their offset up to $5 \mathrm{ka}$ is

919 accounted for by mass balance of radiocarbon in the ocean-atmosphere system. (c)

920 Comparison of atmospheric $\mathrm{pCO}_{2}$ (Monnin et al., 2001; Lemieux-Dudon et al., 2010) and

921 offsets between the observed and modeled $\Delta{ }^{14} \mathrm{C}$ records shown in (a). The mass balance

922 calculation assumes that changes in the marine and atmospheric radiocarbon inventories

923 form a closed and conservative system such that:

$924-\Delta R_{a} \cdot X C O_{2} \cdot M_{a}=\Delta R_{o} \cdot C_{o} \cdot V_{o}$

925 where $\Delta R_{a}$ and $\Delta R_{o}$ are incremental changes in the atmospheric- and average ocean

926 radiocarbon activities, $\mathrm{XCO}_{2}$ is the molar mixing ratio of the atmosphere (assumed

927 equivalent to partial pressure at a nominal pressure of $1 \mathrm{~atm}), M_{a}$ is the molar mass of the

928 atmosphere, $C_{o}$ is the average carbon concentration of the ocean (assumed invariant at

$929 \sim 2.28352 \mathrm{~mol} / \mathrm{m}^{3}$ ), and $V_{o}$ is the volume of the ocean (assumed to equal to $1.3 \times 10^{8} \mathrm{~m}^{3}$ ).

930 Incremental changes in $R_{a}$ were derived at $200 \mathrm{yr}$ time-steps and summed up forward in 931 time.

932

933 Supplementary Fig. S1. $\log (\mathrm{Ca} / \mathrm{Ti})$ of JC089 cores from the Iberian Margin cores

934 correlated to L* of Cariaco Basin for 0 to $80 \mathrm{ka}$ (Deplazes et al., 2013). Individual

935 records have been offset by a constant for illustration purposes.

936

937 Supplementary Fig. S2. $\log (\mathrm{Ca} / \mathrm{Ti})$ of JC089 cores from the Iberian Margin cores 938 correlated to $\mathrm{L}^{*}$ of Cariaco Basin for 0 to $25 \mathrm{ka}$ (Deplazes et al., 2013). Individual

939 records have been offset by a constant for illustration purposes. 
941 Supplementary Fig. S3. $\log (\mathrm{Zr} / \mathrm{Sr})$ of JC089 cores from the Iberian Margin cores 942 correlated to L* of Cariaco Basin for 0 to $80 \mathrm{ka}$ (Deplazes et al., 2013). Individual

943 records have been offset by a constant for illustration purposes.

944

945 Supplementary Fig. S4. $\log (\mathrm{Zr} / \mathrm{Sr})$ of JC089 cores from the Iberian Margin cores

946 correlated to $\mathrm{L}^{*}$ of Cariaco Basin for 0 to $25 \mathrm{ka}$ (Deplazes et al., 2013). Individual

947 records have been offset by a constant for illustration purposes.

948

949 Supplementary Fig. S5. Tie points and sedimentation rates for piston (filled circles) and

950 kasten (filled squares) cores from the Iberian Margin based on correlating XRF $\mathrm{Ca} / \mathrm{Ti}$ and

$951 \mathrm{Zr} / \mathrm{Sr}$ to Cariaco L* for 0 to $80 \mathrm{ka}$. Open squares are the tie points used by Freeman et al.

952 (2016).

953

954 Supplementary Fig. S6. Tie points and sedimentation rates for piston (filled circles) and

955 kasten (filled squares) cores from the Iberian Margin based on correlating XRF $\mathrm{Ca} / \mathrm{Ti}$ and

$956 \mathrm{Zr} / \mathrm{Sr}$ to Cariaco L* for 0 to $25 \mathrm{ka}$. Open squares are the tie points used by Freeman et al. 957 (2016).

958

959 Supplementary Fig. S7. Examples of orthogonal projections of AF demagnetization of

960 natural remanent magnetization (NRM) for JC089 piston cores. Projections for core

961 depths of $100 \mathrm{~cm}, 200 \mathrm{~cm}, 250 \mathrm{~cm}$ and $350 \mathrm{~cm}(300 \mathrm{~cm}$ usually corresponds to a section

962 break). Peak fields are $0,10-30 \mathrm{mT}$ in $5 \mathrm{mT}$ steps, $30-60 \mathrm{mT}$ in $2.5 \mathrm{mT}$ steps and 60-80

$963 \mathrm{mT}$ in $5 \mathrm{mT}$ steps. Intensities are given in $\mathrm{mA} / \mathrm{m}$.

964

965 Supplementary Table 1 . The overall relative paleointensity (RPI) stack, scaled to virtual 966 axial dipole moment (VADM).

967

968 Supplementary Table 2. Geomagnetic intensity proxy based on ${ }^{10} \mathrm{Be}$ flux in Greenland ice 969 cores, resampled at 0-5 kyr intervals, using the GICC05 timescale of Svensson et al. 970 (2008). 
Age (ka)

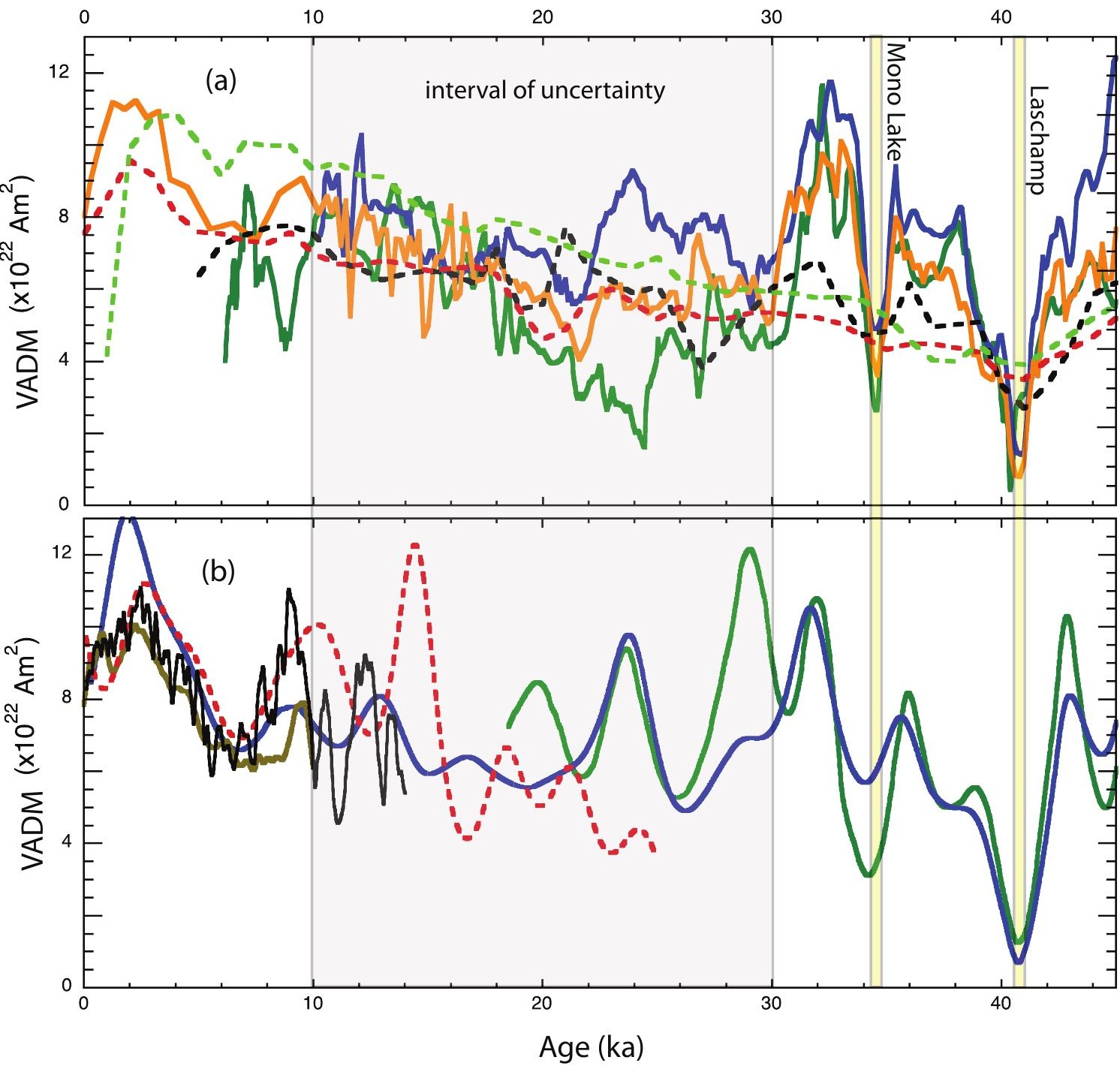


Age (ka)

0

(a)

$40-N^{N} w^{N} M^{N} M^{N}$ BA

స్

N N w w w
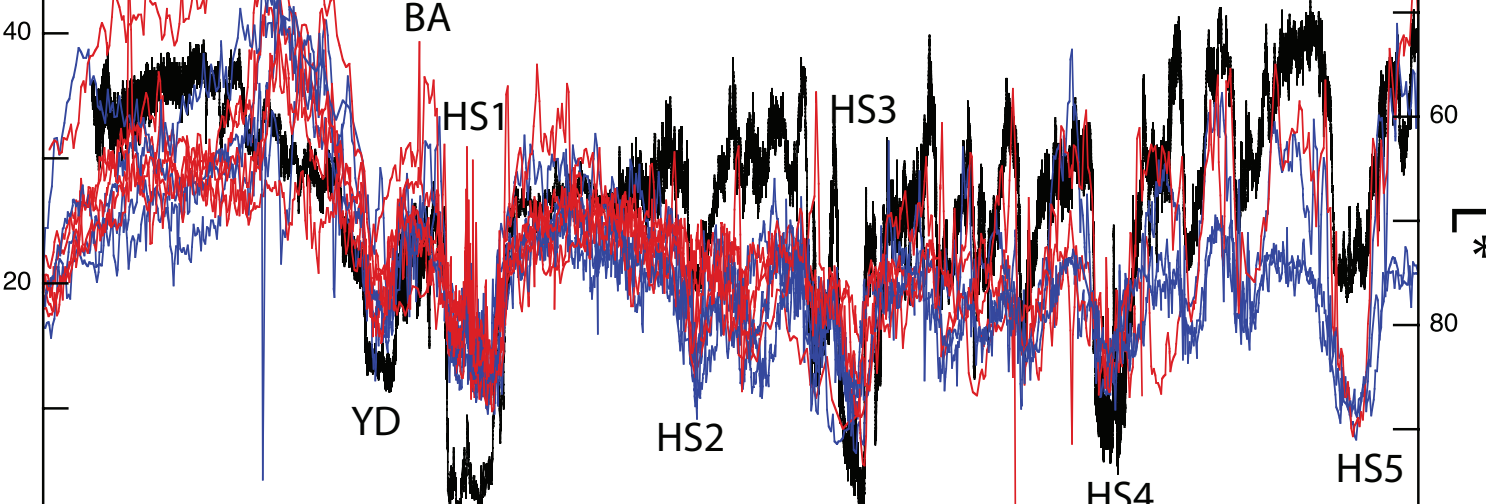

0

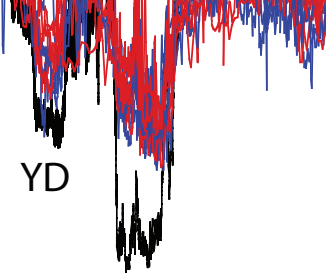

40

HS2
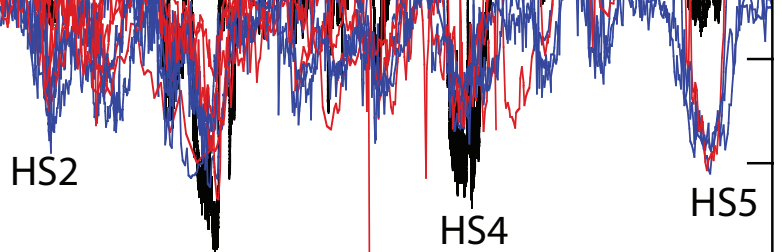

80

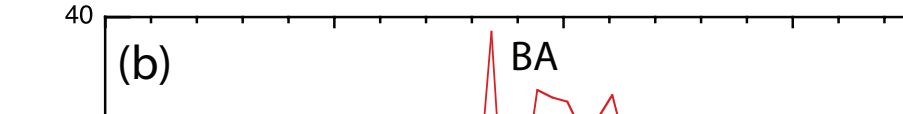


Age (ka)
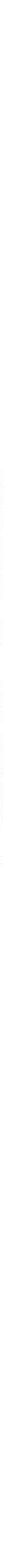


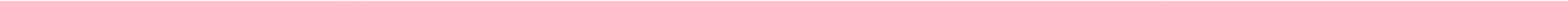




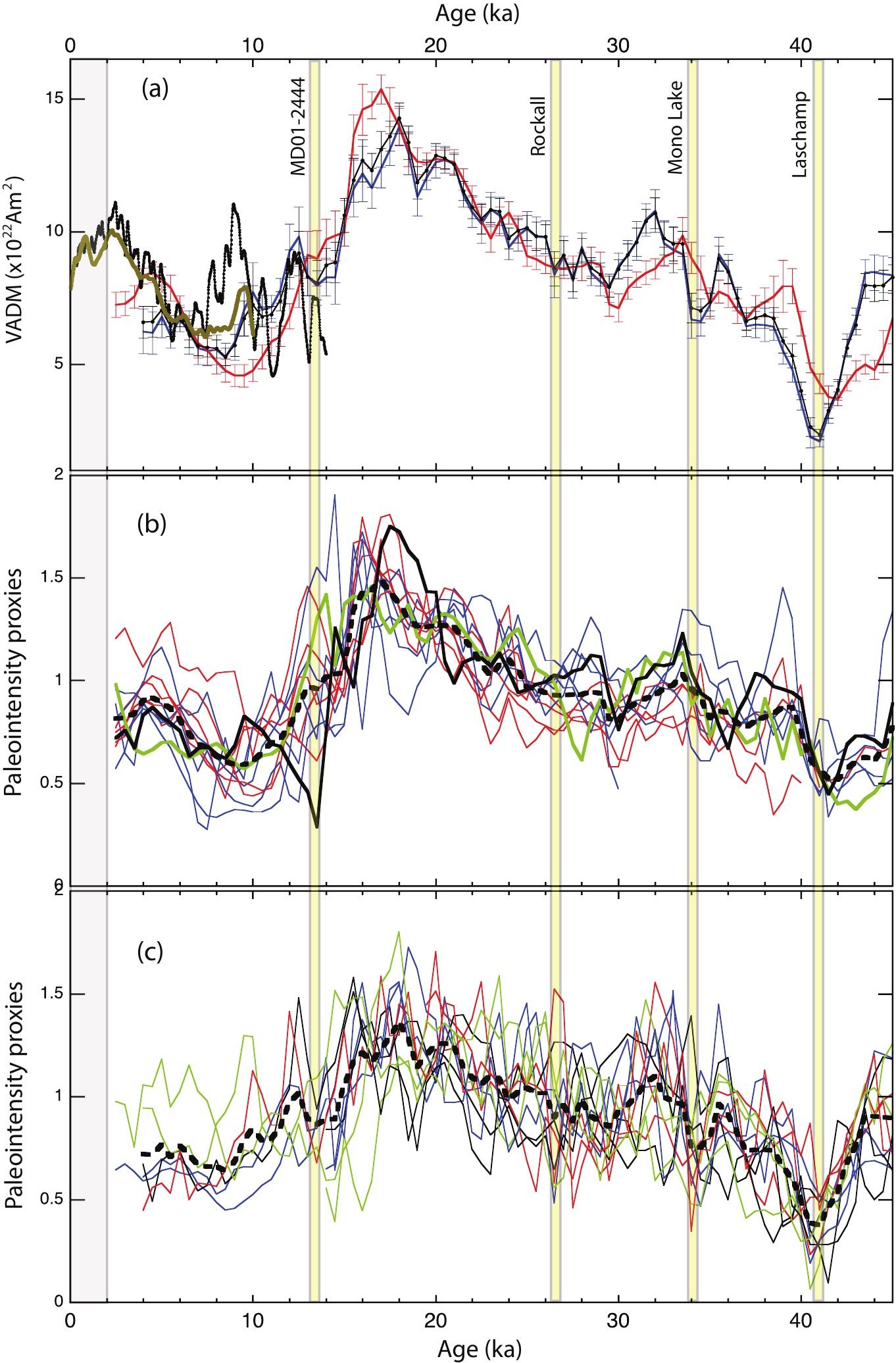




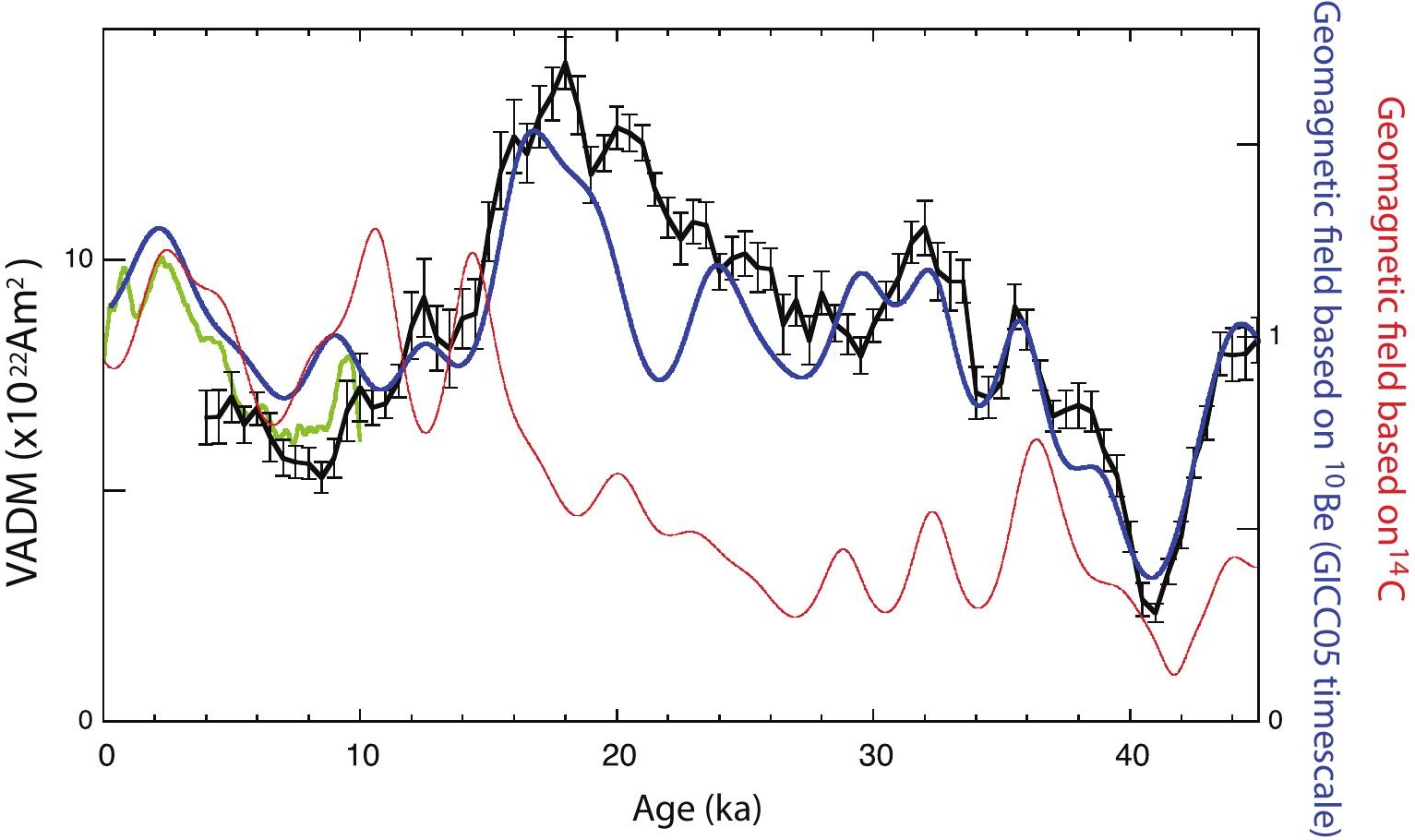




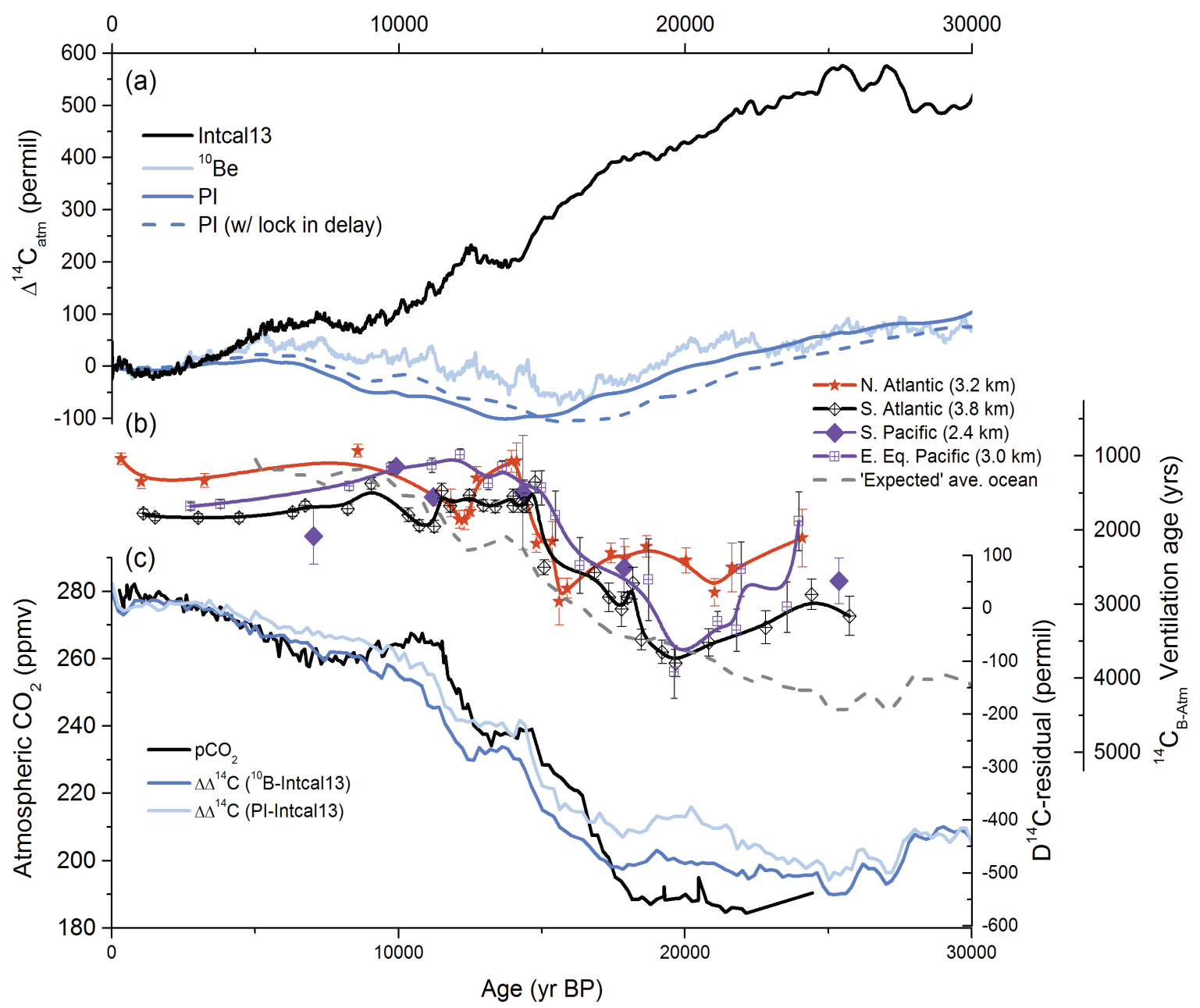




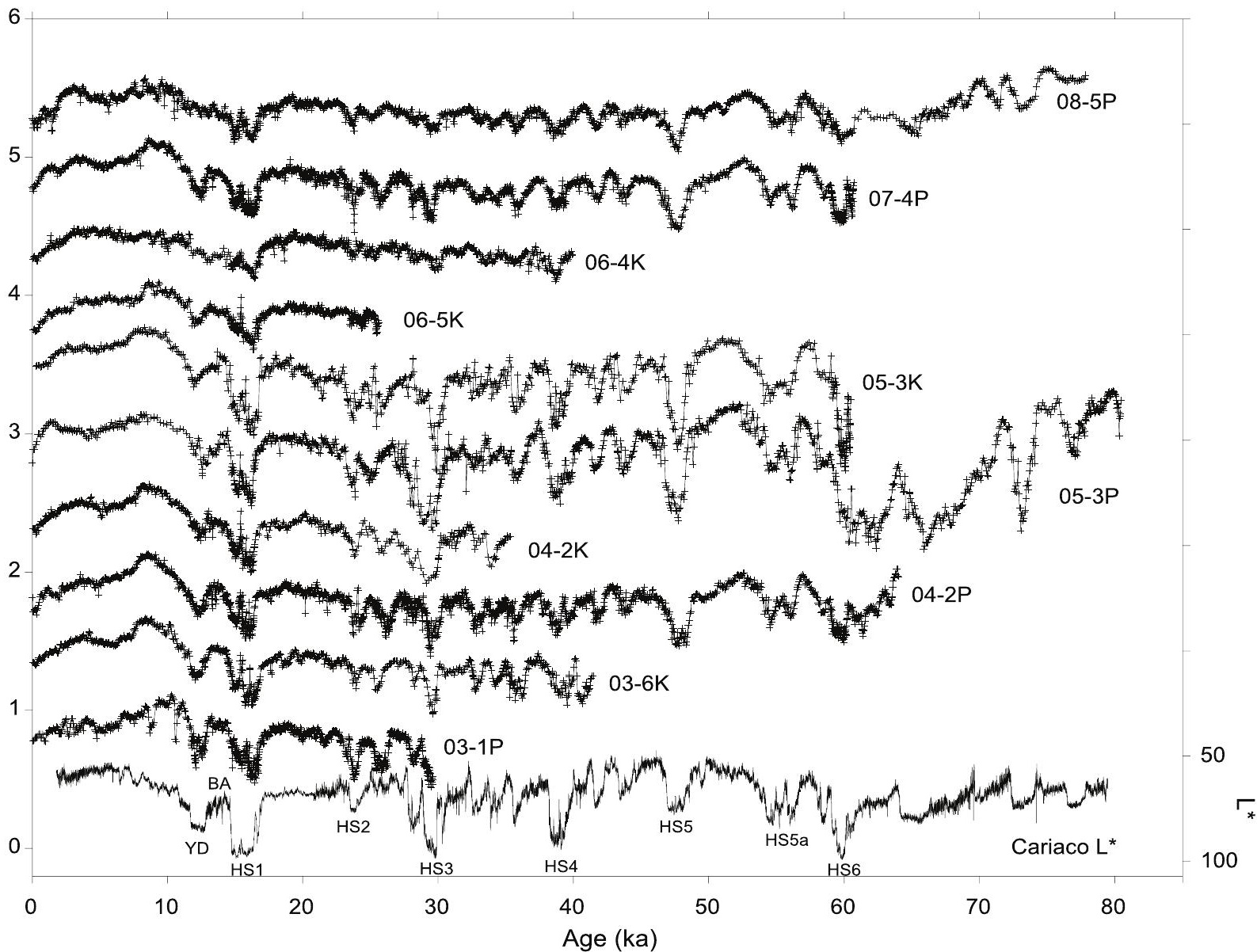




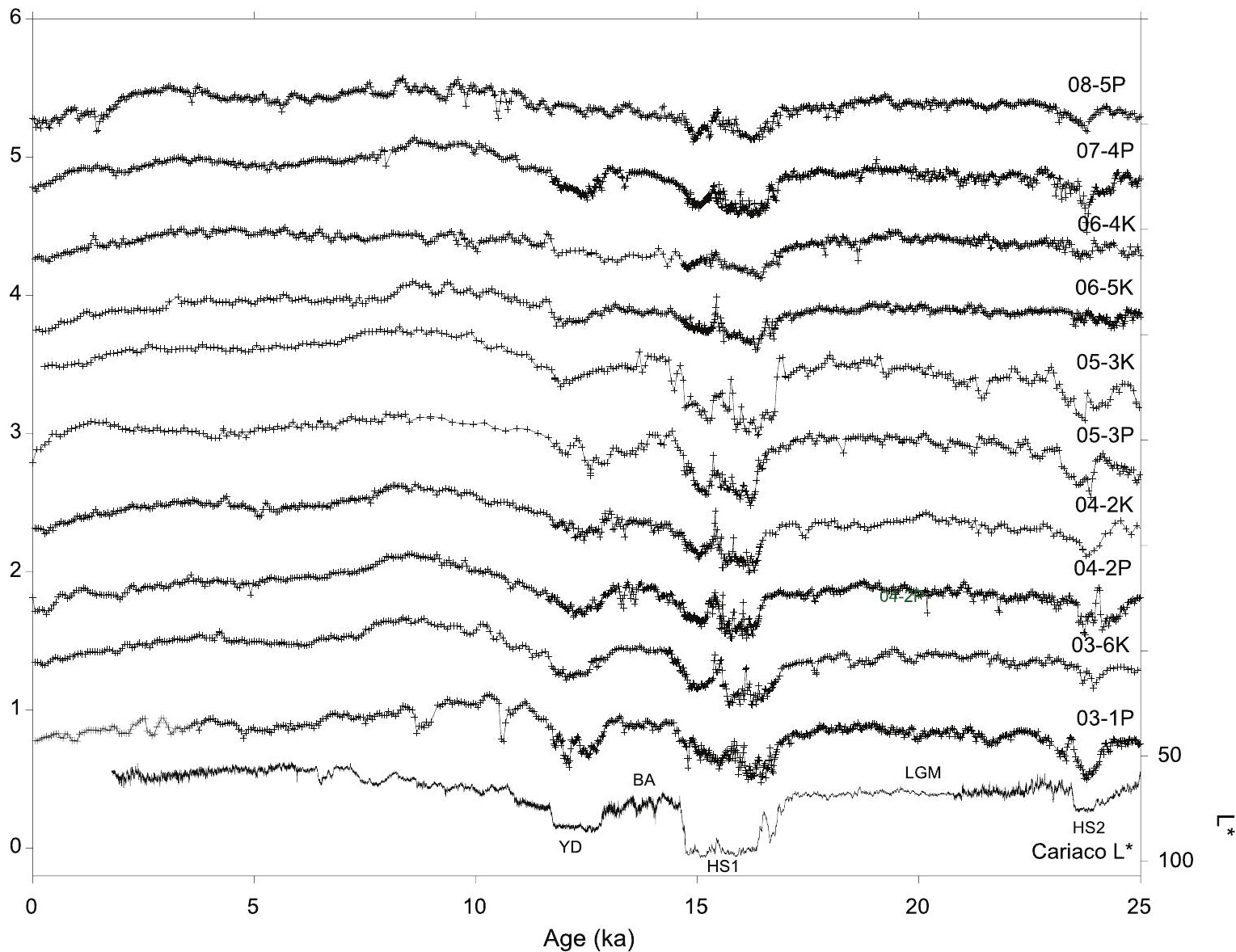




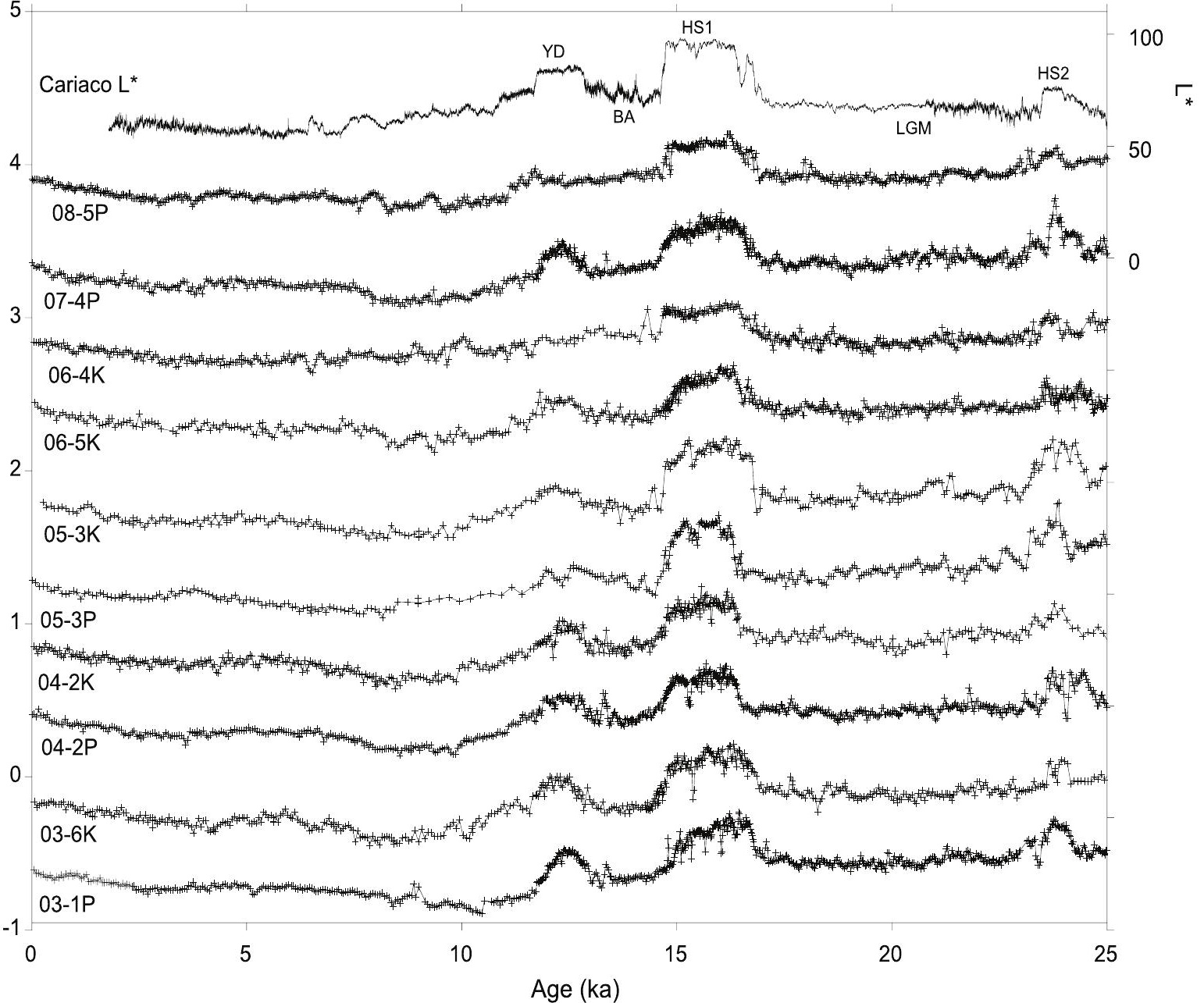




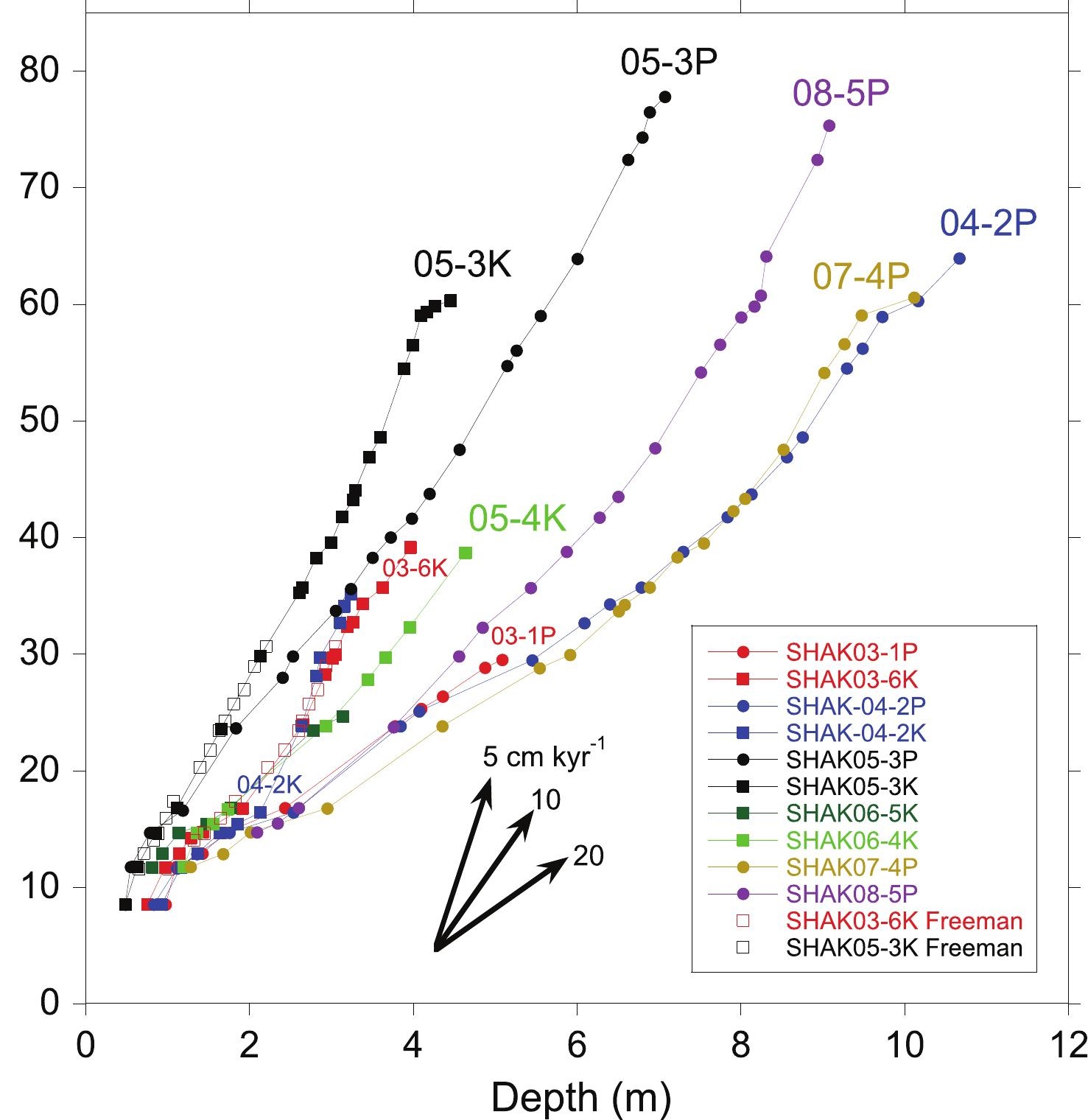




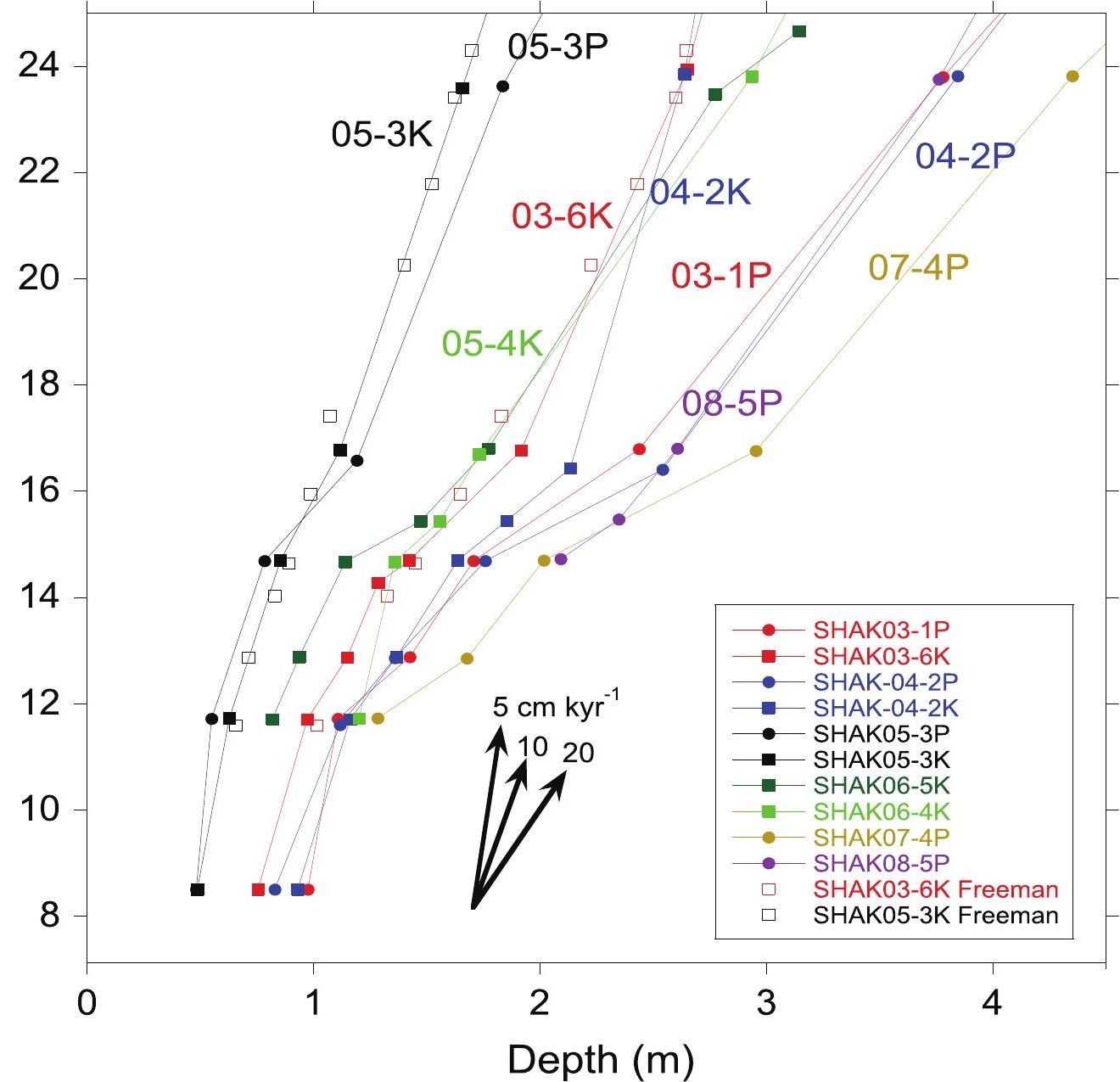


Table 1. JC089 cores included in the SW Iberian Margin stack

\begin{tabular}{|l|l|l|l|l|l|l|l|l|}
\hline $\begin{array}{l}\text { Station } \\
(\text { Fig. } 2)\end{array}$ & Core & Core type & Lat. $\left({ }^{\circ} \mathrm{N}\right)$ & Long. $\left({ }^{\circ} \mathrm{W}\right)$ & WD $(\mathrm{m})$ & $\begin{array}{l}\text { Max. age } \\
(\mathrm{ka})\end{array}$ & $\begin{array}{l}\text { Recovery } \\
(\mathrm{m})\end{array}$ & $\begin{array}{l}\text { Mean sed. rate 10- } \\
45 \mathrm{ka}(\mathrm{cm} / \mathrm{kyr})\end{array}$ \\
\hline 3 & $03-6 \mathrm{~K}$ & Kasten & 37.71 & 10.49 & 3740 & 41 & 4.16 & 10.2 \\
3 & $03-1 \mathrm{P}$ & Piston & 37.71 & 10.49 & 3731 & 30 & 5.14 & 17.2 \\
4 & $04-2 \mathrm{~K}$ & Kasten & 37.59 & 10.36 & 3459 & 35 & 3.25 & 9.25 \\
4 & $04-2 \mathrm{P}$ & Piston & 37.59 & 10.36 & 3470 & $>45$ & 10.69 & 18.3 \\
5 & $05-3 \mathrm{~K}$ & Kasten & 37.60 & 10.69 & 4690 & $>45$ & 4.68 & 7.5 \\
5 & $05-3 \mathrm{P}$ & Piston & 37.60 & 10.69 & 4662 & $>45$ & 7.45 & 9.8 \\
6 & $06-4 \mathrm{~K}$ & Kasten & 37.56 & 10.14 & 2646 & 40 & 4.75 & 12.2 \\
6 & $06-5 \mathrm{~K}$ & Kasten & 37.56 & 10.14 & 2646 & 26 & 3.44 & 12.8 \\
7 & $07-4 \mathrm{P}$ & Piston & 37.85 & 10.15 & 3100 & $>45$ & 10.19 & 18.4 \\
8 & $08-5 \mathrm{P}$ & Piston & 37.78 & 10.05 & 2619 & $>45$ & 9.20 & 15.1 \\
\hline
\end{tabular}


Table 2. Records other than from JC089 (Table 1) included in the RPI stacks for 0-45 ka

\begin{tabular}{|l|l|l|l|l|l|l|}
\hline Site & $\begin{array}{l}\text { Core } \\
\text { type }\end{array}$ & Lat. $\left(^{\circ}\right)$ & $\begin{array}{l}\text { Long. } \\
\left({ }^{\circ}\right)\end{array}$ & $\begin{array}{l}\text { Water } \\
\text { depth }(\mathrm{m})\end{array}$ & $\begin{array}{l}\text { Mean sed rate } \\
(10-45 \mathrm{ka}) \mathrm{cm} / \mathrm{kyr}\end{array}$ & Ref. \\
\hline & & & & & & \\
MD01-2444 (SW Iberia)* & CAL & $37.6 \mathrm{~N}$ & $10.1 \mathrm{~W}$ & $\sim 3162$ & 28 & 1 \\
Portuguese Margin Stack* & CAL & $39.0 \mathrm{~N}$ & $10.2 \mathrm{~W}$ & 2344 & & 25 \\
Lac du Bouchet (France) & LC & $4.9 \mathrm{~N}$ & $3.8 \mathrm{E}$ & & 22.2 & 3 \\
Lake Biwa (Japan) & PC & $35.2 \mathrm{~N}$ & $136.1 \mathrm{E}$ & 67 & 40 & 4 \\
Lake Potrok Aike (Patagonia) & PC & $52.0 \mathrm{~S}$ & $70.4 \mathrm{~W}$ & 100 & 66 & 5 \\
Lake Van (Turkey) & PC & $38.6 \mathrm{~N}$ & $42.7 \mathrm{E}$ & 360 & 40 & 6 \\
Lake Towuti (Indonesia) & KPC & $2.8 \mathrm{~S}$ & $121.5 \mathrm{E}$ & 154 & 19 & 7 \\
Black Sea & GC & $42.0 \mathrm{~N}$ & $37.0 \mathrm{E}$ & $200-800$ & 60 & 8 \\
MD04-2822 (Rockall Trough) & PC & $56.8 \mathrm{~N}$ & $11.4 \mathrm{~W}$ & 2637 & 54 & 9 \\
ODP 1063 (Bermuda Rise) & APC & $33.7 \mathrm{~N}$ & $57.6 \mathrm{~W}$ & 4584 & 61 & 10 \\
CH88-10p (Bermuda Rise) & PC & $29.6 \mathrm{~N}$ & $19.3 \mathrm{~W}$ & 3818 & 23 & 11 \\
MD98-2181 (Philippines) & CAL & $6.3 \mathrm{~N}$ & $125.8 \mathrm{E}$ & 2114 & 43 & 12 \\
ODP 1089 (South Atlantic) & APC & $40.9 \mathrm{~S}$ & $9.9 \mathrm{E}$ & 4620 & 20 & 14 \\
PS67-197-1 (Scotia Sea) & PC & $55.1 \mathrm{~S}$ & $44.1 \mathrm{~W}$ & 3837 & 31 & \\
\hline
\end{tabular}

* included in SW Iberian Margin stack

Core type: LC Livingstone corer; KPC Kullenberg piston corer; PC piston corer; GC gravity corer; CAL Calypso corer (MD), APC Advanced piston corer (ODP).

References: (1) Channell et al. (2013), (2) Thouveny et al. (2004), (3) Thouveny et al. (1993), (4)

Hayashida et al. (2007); (5) Lisé-Pronovost et al. (2013); (6) Vigilotti et al. (2014), (7) Kirana et al. (2018), (8) Nowaczyk et al. (2013), (9) Channell et al. (2016), (10) Channell et al. (2012), (11) Schwartz et al. (1996), (12) Stott et al. (2002), (13) Stoner et al. (2003), (14) Xiao et al. (2016). 


\begin{tabular}{|c|c|c|c|c|c|}
\hline Age (ka) & $\begin{array}{l}\text { VADM } \\
\left(\mathrm{x} 10^{22} \mathrm{Am}^{2}\right)\end{array}$ & Std. error & Age (ka) & $\begin{array}{l}\text { VADM } \\
\left(\mathrm{x} 10^{22} \mathrm{Am}^{2}\right)\end{array}$ & Std. error \\
\hline 4.00 & 6.585 & 0.592 & 25.00 & 10.136 & 0.478 \\
\hline 4.50 & 6.604 & 0.585 & 25.50 & 9.833 & 0.537 \\
\hline 5.00 & 7.032 & 0.541 & 26.00 & 9.800 & 0.450 \\
\hline 5.50 & 6.432 & 0.391 & 26.50 & 8.600 & 0.648 \\
\hline 6.00 & 6.777 & 0.354 & 27.00 & 9.112 & 0.538 \\
\hline 6.50 & 6.162 & 0.522 & 27.50 & 8.257 & 0.520 \\
\hline 7.00 & 5.705 & 0.391 & 28.00 & 9.283 & 0.462 \\
\hline 7.50 & 5.625 & 0.350 & 28.50 & 8.627 & 0.389 \\
\hline 8.00 & 5.587 & 0.343 & 29.00 & 8.384 & 0.430 \\
\hline 8.50 & 5.284 & 0.334 & 29.50 & 7.926 & 0.396 \\
\hline 9.00 & 5.708 & 0.417 & 30.00 & 8.581 & 0.360 \\
\hline 9.50 & 6.728 & 0.655 & 30.50 & 9.119 & 0.419 \\
\hline 10.00 & 7.238 & 0.728 & 31.00 & 9.601 & 0.535 \\
\hline 10.50 & 6.798 & 0.374 & 31.50 & 10.386 & 0.445 \\
\hline 11.00 & 6.881 & 0.308 & 32.00 & 10.695 & 0.587 \\
\hline 11.50 & 7.380 & 0.355 & 32.50 & 9.746 & 0.620 \\
\hline 12.00 & 8.573 & 0.725 & 33.00 & 9.533 & 0.636 \\
\hline 12.50 & 9.179 & 0.835 & 33.50 & 9.533 & 0.472 \\
\hline 13.00 & 8.303 & 0.703 & 34.00 & 7.120 & 0.566 \\
\hline 13.50 & 8.078 & 0.847 & 34.50 & 7.016 & 0.452 \\
\hline 14.00 & 8.731 & 0.641 & 35.00 & 7.346 & 0.335 \\
\hline 14.50 & 8.830 & 0.764 & 35.50 & 8.984 & 0.481 \\
\hline 15.00 & 10.615 & 0.646 & 36.00 & 8.483 & 0.430 \\
\hline 15.50 & 11.935 & 0.828 & 36.50 & 7.497 & 0.326 \\
\hline 16.00 & 12.676 & 0.796 & 37.00 & 6.617 & 0.327 \\
\hline 16.50 & 12.309 & 0.647 & 37.50 & 6.758 & 0.409 \\
\hline 17.00 & 13.101 & 0.667 & 38.00 & 6.847 & 0.497 \\
\hline 17.50 & 13.593 & 0.569 & 38.50 & 6.719 & 0.425 \\
\hline 18.00 & 14.267 & 0.570 & 39.00 & 5.875 & 0.450 \\
\hline 18.50 & 13.356 & 0.632 & 39.50 & 5.326 & 0.450 \\
\hline 19.00 & 11.847 & 0.613 & 40.00 & 4.006 & 0.329 \\
\hline 19.50 & 12.314 & 0.387 & 40.50 & 2.639 & 0.356 \\
\hline 20.00 & 12.867 & 0.458 & 41.00 & 2.354 & 0.201 \\
\hline 20.50 & 12.756 & 0.396 & 41.50 & 3.244 & 0.270 \\
\hline 21.00 & 12.537 & 0.378 & 42.00 & 4.045 & 0.296 \\
\hline 21.50 & 11.528 & 0.359 & 42.50 & 5.612 & 0.331 \\
\hline 22.00 & 10.918 & 0.435 & 43.00 & 6.472 & 0.369 \\
\hline 22.50 & 10.462 & 0.555 & 43.50 & 7.964 & 0.467 \\
\hline 23.00 & 10.823 & 0.476 & 44.00 & 7.942 & 0.570 \\
\hline 23.50 & 10.752 & 0.503 & 44.50 & 7.970 & 0.568 \\
\hline 24.00 & 9.744 & 0.389 & 45.00 & 8.266 & 0.494 \\
\hline 24.50 & 10.034 & 0.462 & & & \\
\hline
\end{tabular}




\begin{tabular}{|c|c|c|c|}
\hline Age (ka) & ${ }^{10} \mathrm{Be}-$ based intensity & Age $(\mathrm{ka})$ & ${ }^{10} \mathrm{Be}$-based intensity \\
\hline 0.50 & 1.098 & 23.00 & 1.068 \\
\hline 1.00 & 1.163 & 23.50 & 1.158 \\
\hline 1.50 & 1.234 & 24.00 & 1.186 \\
\hline 2.00 & 1.278 & 24.50 & 1.146 \\
\hline 2.50 & 1.270 & 25.00 & 1.077 \\
\hline 3.00 & 1.211 & 25.50 & 1.011 \\
\hline 3.50 & 1.133 & 26.00 & 0.960 \\
\hline 4.00 & 1.066 & 26.50 & 0.921 \\
\hline 4.50 & 1.019 & 27.00 & 0.897 \\
\hline 5.00 & 0.985 & 27.50 & 0.900 \\
\hline 5.50 & 0.949 & 28.00 & 0.944 \\
\hline 6.00 & 0.904 & 28.50 & 1.028 \\
\hline 6.50 & 0.862 & 29.00 & 1.120 \\
\hline 7.00 & 0.841 & 29.50 & 1.166 \\
\hline 7.50 & 0.858 & 30.00 & 1.143 \\
\hline 8.00 & 0.910 & 30.50 & 1.097 \\
\hline 8.50 & 0.973 & 31.00 & 1.085 \\
\hline 9.00 & 1.004 & 31.50 & 1.124 \\
\hline 9.50 & 0.978 & 32.00 & 1.170 \\
\hline 10.00 & 0.918 & 32.50 & 1.145 \\
\hline 10.50 & 0.871 & 33.00 & 1.026 \\
\hline 11.00 & 0.865 & 33.50 & 0.894 \\
\hline 11.50 & 0.901 & 34.00 & 0.825 \\
\hline 12.00 & 0.953 & 34.50 & 0.844 \\
\hline 12.50 & 0.981 & 35.00 & 0.937 \\
\hline 13.00 & 0.967 & 35.50 & 1.031 \\
\hline 13.50 & 0.935 & 36.00 & 1.014 \\
\hline 14.00 & 0.928 & 36.50 & 0.885 \\
\hline 14.50 & 0.977 & 37.00 & 0.750 \\
\hline 15.00 & 1.094 & 37.50 & 0.673 \\
\hline 15.50 & 1.262 & 38.00 & 0.657 \\
\hline 16.00 & 1.428 & 38.50 & 0.663 \\
\hline 16.50 & 1.523 & 39.00 & 0.635 \\
\hline 17.00 & 1.529 & 39.50 & 0.552 \\
\hline 17.50 & 1.487 & 40.00 & 0.452 \\
\hline 18.00 & 1.442 & 40.50 & 0.386 \\
\hline 18.50 & 1.410 & 41.00 & 0.377 \\
\hline 19.00 & 1.370 & 41.50 & 0.427 \\
\hline 19.50 & 1.295 & 42.00 & 0.533 \\
\hline 20.00 & 1.179 & 42.50 & 0.673 \\
\hline 20.50 & 1.049 & 43.00 & 0.820 \\
\hline 21.00 & 0.945 & 43.50 & 0.943 \\
\hline 21.50 & 0.892 & 44.00 & 1.018 \\
\hline 22.00 & 0.900 & 44.50 & 1.031 \\
\hline 22.50 & 0.966 & 45.00 & 0.991 \\
\hline
\end{tabular}

